\title{
Environmental Friendly Multi-step Processing of Efficient Mixed-cation Mixed Halide Perovskite Solar Cells from Chemically Bath Deposited Lead Sulphide
}

\section{Sahel Gozalzadeh}

Sahand University of Technology

Farzad Nasirpouri ( $\nabla$ f_nasirpouri@yahoo.com )

Sahand University of Technology

\section{Sang II Seok}

Ulsan National Institute of Science and Technology

\section{Research Article}

Keywords: Organic-inorganic hybrid perovskite, solar cells, dimethylformamide (DMF), spin coating methods

Posted Date: June 2nd, 2021

DOl: https://doi.org/10.21203/rs.3.rs-569032/v1

License: (c) (1) This work is licensed under a Creative Commons Attribution 4.0 International License. 


\section{Environmental friendly multi-step processing of efficient mixed-cation mixed halide perovskite solar cells from chemically bath deposited lead sulphide}

Sahel Gozalzadeh ${ }^{1}$, Farzad Nasirpouri ${ }^{1, *}$, Sang Il Seok ${ }^{2}$

${ }^{1}$ Faculty of Materials Engineering, Sahand University of Technology, Tabriz 51335-1996, Iran

${ }^{2}$ School of Energy and Chemical Engineering, Ulsan National Institute of Science and Technology

(UNIST), 50 UNIST-gil, Eonyang-eup, Ulju-gun, Ulsan 689-798, Republic of Korea

*-Corresponding author: nasirpouri@sut.ac.ir; __nasirpouri@yahoo.com 


\begin{abstract}
Organic-inorganic hybrid perovskite is the most promising active layer for new generation of solar cells. Despite of highly efficient perovskite active layer conventionally fabricated by spin coating methods, the need for using toxic solvents like dimethylformamide (DMF) required for dissolving low soluble metal precursors as well as the difficulties for upscaling the process have restricted their practical development. To deal with these shortcomings, in this work, lead sulphide as the lead metal precursor was produced by aqueous chemical bath deposition. $\mathrm{PbS}$ films were subsequently chemically converted to $\mathrm{PbI}_{2}$ and finally to mixed-cation mixed halide perovskite films. The microstructural, optical and solar cell performance of mixed cation mixed halide perovskite films were exploited. Results show that controlling the morphology of $\mathrm{PbI}_{2}$ platelets achieved from $\mathrm{PbS}$ precursor films enabled efficient conversion to perovskite. Using this processing technique, smooth and pin hole-free perovskite films having columnar grains of about $800 \mathrm{~nm}$ and a bandgap of $1.55 \mathrm{eV}$ were produced. The solar cell performance consisting of such perovskite layers gave rise to a notable power conversion efficiency of $11.35 \%$ under standard solar conditions. The proposed processing technique is a very promising environmentally friendly method for the production of large-scale high efficient perovskite solar cells.
\end{abstract}




\section{Introduction}

Organolead halide perovskites with $\mathrm{ABX}_{3}$ formula (A: methylammonium (MA), formamidinium (FA); $\mathrm{B}$ : $\mathrm{Pb}, \mathrm{Sn}$, etc.; $\left.\mathrm{X}: \mathrm{Cl}^{-}, \mathrm{I}^{-}, \mathrm{Br}^{-}\right)^{1}$ are of great interest for solar cell applications owing to their remarkable properties, such as high absorption coefficient ${ }^{2}$, weak electron-hole binding energy ${ }^{3,4}$, adjustable and direct band gap $^{5}$ and long charge carrier diffusion length ${ }^{6}$ and also facile cost-effective fabrication methods. The phenomenal performances of these alluring absorbing layers have skyrocketed their power conversion efficiencies (PCEs) from $3.8 \%^{7}$ to over $25.2 \%^{8}$ in a short period of ten years for perovskite solar cell (PSC) devices.

Two main routes widely used for synthesizing organometal halide perovskites are single step and sequential deposition methods. For the former one, a solution including both perovskite precursors $\left(\mathrm{PbX} 2(\mathrm{X}: \mathrm{I}, \mathrm{Cl}, \mathrm{Br})\right.$ and $\mathrm{MAX}\left(\mathrm{MA}^{+}=\left(\mathrm{CH}_{3} \mathrm{NH}_{3}\right)^{+}\right)$or $\mathrm{FAX}\left(\mathrm{FA}^{+}=\left(\mathrm{CH}\left(\mathrm{NH}_{2}\right)_{2}\right)^{+}\right)$is deposited via methods like spin coating ${ }^{9}$, spray deposition ${ }^{10}$, blade coating ${ }^{11}$, inkjet printing ${ }^{12}$ and slot die coating ${ }^{13}$ onto a substrate to form the perovskite material. Indeed, the uncontrollable precipitation of the perovskite by a single-step method often results in low reproducibility, morphological variations and a wide spread of photovoltaic performance of the devices ${ }^{14}$. To address these problems, the sequential deposition method was introduced with $\mathrm{PbI}_{2}$ layer being deposited from either a solution ${ }^{14}$ phase or a vapor ${ }^{15}$ phase onto substrate firstly and following conversion into perovskite by exposing to a MAX $\left(\mathrm{MA}^{+}=\left(\mathrm{CH}_{3} \mathrm{NH}_{3}\right)^{+}\right)$or FAX $\left(\mathrm{FA}^{+}=\left(\mathrm{CH}\left(\mathrm{NH}_{2}\right)_{2}\right)^{+}\right)$solution or vapor, which better controls the perovskite morphology and its stoichiometry and crystallinity. Therefore, the possibility of photovoltaic enhancement has been shown to be higher with this method ${ }^{14}$ and is anticipated that new routes with further modifications will be required to ever enhance the solar cell performance in this way. For instance, the poor solubility of $\mathrm{PbI}_{2}$ and utilization of toxic solvents like dimethylformamide (DMF) makes the first step of the sequential deposition method, i.e., depositing $\mathrm{PbI}_{2}$ layer, not well recommended and suitable for upscaling for mass production. One approach for dealing with this problem is to use water-based metal precursor compounds. 
There has been a recent trend with respect to the development of such two- or multi-step processing routes for the production of the metal halide perovskite films and solar cells from water-based metal precursors. The general procedure employed is to firstly deposit metal (M) precursor film followed by iodination leading to $\mathrm{MI}_{2}$. This finally is chemically converted to MAX perovskite films. In addition, direct conversion of metal precursor to final perovskite has also been reported. A few metal precursors such as $\mathrm{Pb}^{16}, \mathrm{PbO}^{17,18}, \mathrm{PbO}_{2}{ }^{19,20}, \mathrm{~Pb}\left(\mathrm{NO}_{3}\right)_{2}{ }^{21-24}, \mathrm{PbSe}^{25}$ and $\mathrm{PbS}^{26-29}$, have been developed via different deposition approaches including chemical, physical and electrochemical methods . Table S1 summarizes different metal precursors, their processing towards the fabrication of PSC and highest PCE of the cell reported.

Lead sulphide $(\mathrm{PbS})$ is a non-halide compound with a lower bond dissociation energy $(3.3 \mathrm{eV})$ compared to oxide precursors ${ }^{30}$ and therefore more chemically reactive which facilities its subsequent reduction to final perovskite films. $\mathrm{PbS}$ can be deposited by various techniques such as vacuum evaporation ${ }^{31}$, spray pyrolysis $^{32}$, successive ionic layer adsorption and reaction ${ }^{33}$, electrodeposition ${ }^{34}$, molecular beam epitaxy $^{35}$, and chemical bath deposition (CBD) $)^{36,37}$.

In addition to methods already developed for depositing $\mathrm{PbS}$, some of them have been employed in combination with solution processing to produce final lead halide perovskite film and PSCs. Sutherland et al. ${ }^{26}$ have reported atomic layer deposition of lead sulphide $(\mathrm{PbS})$ layer for the first time. The deposit was in the form of $75 \mathrm{~nm}$ thin film and introduced as a precursor material to be converted into the final perovskite layer ${ }^{26}$. Successive exposure to iodine vapor and methylammonium bromide was used to directly converting of two-dimensional (2D) $\mathrm{PbS}$ nanocrystals into nanocrystals of hybrid perovskite maintaining 2D morphology ${ }^{38}$. Radio-frequency sputtering assisted solution process has also been employed for depositing $\mathrm{PbS}$ films which were converted into the perovskite layer by exposing in an iodine atmosphere at room temperature, followed by immersing in a methylammonium iodide solution to be transformed to the perovskite layer ${ }^{27}$. CBD technique combined with chemical vapor deposition (CVD) has been proved to be applicable for synthesizing lead halide perovskite films whose power conversion efficiency has been reported $4.68 \%$ in a $\mathrm{PSC}^{28}$. We have recently demonstrated that lead halide perovskite films and cells were successfully fabricated based on electrodeposited $\mathrm{PbS}^{29}$ with a champion efficieny of 
7.72\%. The proposed work of electrodeposition of $\mathrm{PbS}$ and subsequent solution based processing towards fabrication of lead halide perovskite films provided complex interfacial electrode reactions and nucleation and growth with cuboidal grain morphology with uneven interlayer junctions which delays the charge carrier transportation and increases the recombination rates before hitting the hole transport layer.

CBD has been established as a distinct method of depositing PbS with controllable morphology along with its scalability, simplicity, low-cost and low temperature ${ }^{39-41}$. As explained above there is only one report of using CBD for depositing precursor of lead sulphide, which is combined with CVD method for final conversion to lead halide perovskite.

In most of reports related to using an alternative precursor material, the final product is $\mathrm{MAPbI}_{3} . \mathrm{FAPbI}_{3}$ is known with its broader absorption spectrum and narrower bandgap material than $\mathrm{MAPbI}_{3}$, however, its morphology and phase structure have significant effects on its performance in perovskite solar cells. In most cases, the $\mathrm{PCE}$ of $\mathrm{FAPbI}_{3}$ based inverted planar devices are lower than those of $\mathrm{MAPbI}_{3}$ because of the inferior morphology of $\mathrm{FAPbI}_{3}$ film. It is well known that the performance of devices based on $\mathrm{MAPbI}_{3}$ would degrade greatly in high temperature or high humidity level. $\mathrm{FAPbI}_{3}$ is more stable than $\mathrm{MAPbI}_{3}$, but it has an undesirable phase transition between $\delta$-phase (yellow phase-more stable) and perovskite $\alpha$-phase (black phase) at different temperatures ${ }^{42}$. Adding small amount of $\mathrm{MA}^{+}$induces crystallization of black phase of FA-based perovskite and inhibit the phase transition ${ }^{43}$. Therefore, mixing anions and cations is an important approach to provide high performance and stable devices.

Therefore, in this work, we employed a toxic solvent-free route based on CBD to deposit PbS as the lead metal precursor film is introduced for fabricating perovskite films with the mixed cations (FA, MA) and mixed halides ( $\mathrm{I}, \mathrm{Br}, \mathrm{Cl}$ ). The process started with the chemical bath deposition of a $\mathrm{PbS}$ seeding layer. Then, $\mathrm{PbS}$ film was exposed to iodine vapor to chemically convert to $\mathrm{PbI}_{2}$. Depending on temperature of iodination, the morphology of $\mathrm{PbI}_{2}$ layer changed. The effect of different morphologies on final step i.e. chemical conversion to perovskite film and also photovoltaic performance of achieved layers in the perovskite solar cell studied. This study represents the versatility of proposed route to produce fully covered and high quality perovskite layer. After current optimization, the power conversion efficiency 
(PCE) of $11.35 \%$ was achieved under standard condition (air mass (AM) $1.5,100 \mathrm{~mW} \mathrm{~cm}^{-2}$ ) with potential enhancement after several trials in future.

\section{Results and discussion}

\section{Chemical bath deposition of PbS films}

Figure 1a shows the XRD pattern of chemically deposited $\mathrm{PbS}$ layer. As is evident from the XRD pattern, $\mathrm{PbS}$ thin film exhibits a face-centered-cubic (fcc) microstructure. The main Bragg diffraction peaks located at $25.78^{\circ}, 30.548^{\circ}, 43.32^{\circ}$ correspond to (111), (200) and (220) crystalline planes, respectively (JCPDS No.00-05-0592). Except the peaks of PbS and substrate (FTO and $\left.\mathrm{TiO}_{2}\right)$, no other peaks were detected which certified the purity of the deposited $\mathrm{PbS}$ film. The film formation in the chemical bath deposition method starts with the supersaturation of the solution which results in the production of contents of cations and anions exceeding the solubility. Taking this point into account, the formation of $\mathrm{PbS}$ from aforementioned chemical bath includes following steps: dissolving $\mathrm{Pb}\left(\mathrm{CH}_{3} \mathrm{COO}\right)_{2}$ in aqueous solution results into the formation of $\mathrm{Pb}^{2+}$ ions. Dissociation of thiourea in solution leads to release of $\mathrm{SH}^{-}$ ions. $\mathrm{SH}^{-}$ions go through reaction with hydroxide species to produce $\mathrm{S}^{2-}$ anions. Finally, $\mathrm{PbS}$ thin film forms via adsorbing of $\mathrm{Pb}^{2+}$ cations on substrate and combining with $\mathrm{S}^{2-}$ anions. The overall growth of $\mathrm{PbS}$ film takes place by ion-by-ion process on the substrate. The corresponding reactions are as follows $\left(\right.$ reactions 1-4) ${ }^{44}$ :

$$
\begin{array}{lr}
\mathrm{Pb}\left(\mathrm{CH}_{3} \mathrm{COO}\right)_{2} \rightarrow \mathrm{Pb}^{2+}+2 \mathrm{CH}_{3} \mathrm{COO}^{-} & \mathbf{1} \\
\mathrm{SC}\left(\mathrm{NH}_{2}\right)_{2}+\mathrm{OH}^{-} \rightarrow \mathrm{CH}_{2} \mathrm{~N}_{2}+\mathrm{H}_{2} \mathrm{O}+\mathrm{SH}^{-} & \mathbf{2} \\
\mathrm{SH}^{-}+\mathrm{OH}^{-} \rightarrow \mathrm{S}^{2-}+\mathrm{H}_{2} \mathrm{O} & \mathbf{3} \\
\mathrm{Pb}^{2+}+\mathrm{S}^{2-} \rightarrow \mathrm{PbS} & \mathbf{4}
\end{array}
$$

SEM micrographs taken from top (Figure 1b) of the chemically deposited PbS shows a compact structure which consists of smooth, uniform spherical and densely packed grains. The film well covers the substrate 
completely. The thickness of $\mathrm{PbS}$ layers deposited for various immersion time of the substrate inside the bath, as well as the thickness of corresponding $\mathrm{PbI}_{2}$ and perovskite films, was measured and summarized in Table S2.

Figure 1c represents the AFM image of the $\mathrm{PbS}$ thin film deposited on the $\mathrm{mp}-\mathrm{TiO}_{2} / \mathrm{bl}-\mathrm{TiO}_{2} / \mathrm{FTO}$ substrate. It indicates that the $\mathrm{PbS}$ thin film is composed of particles of granular nature which are smoothly and uniformly distributed on the surface. The root-mean-square roughness $(R q)$ of film is measured about $31.3 \mathrm{~nm}$. Furthermore, the particle size distribution histogram calculated on the SEM image is shown in Figure 1d. Accordingly, the average size of granular grains of $\mathrm{PbS}$ is approximately $119 \mathrm{~nm}$. The formation of uniform compact grains in the microstructure of PbS films is achieved as a consequence of multiple nucleation followed by one-step growth ${ }^{45}$.

Evaluating the morphology and composition of obtained film showed that the $\mathrm{PbS}$ thin film deposited through dipping the substrates inside chemical bath for $60 \mathrm{~min}$ have low surface roughness and full coverage of electron transport layer (ETL) layer. Thus, it is a good candidate for using as a precursor layer for preparing final lead halide perovskite film.

\section{Chemical conversion of $\mathrm{PbS}$ to $\mathrm{PbI}_{2}$ films}

The iodination of chemically deposited $\mathrm{PbS}$ films were carried out by putting $\mathrm{PbS}$ films in iodine vapor environment at two different temperatures of 120 and $155^{\circ} \mathrm{C}$. From XRD patterns (Figure 2a,b), it is obvious that whole $\mathrm{PbS}$ is converted to $\mathrm{PbI}_{2}$ and instead of initial $\mathrm{PbS}$ peaks, some new peaks can be seen which are in accordance with crystallite planes of $\mathrm{PbI}_{2}(00-007-0235)$. The possible reaction can be ${ }^{27}$ :

$\mathrm{PbS}+\mathrm{I}_{2} \rightarrow \mathrm{PbI}_{2}+\mathrm{S} \uparrow$ 


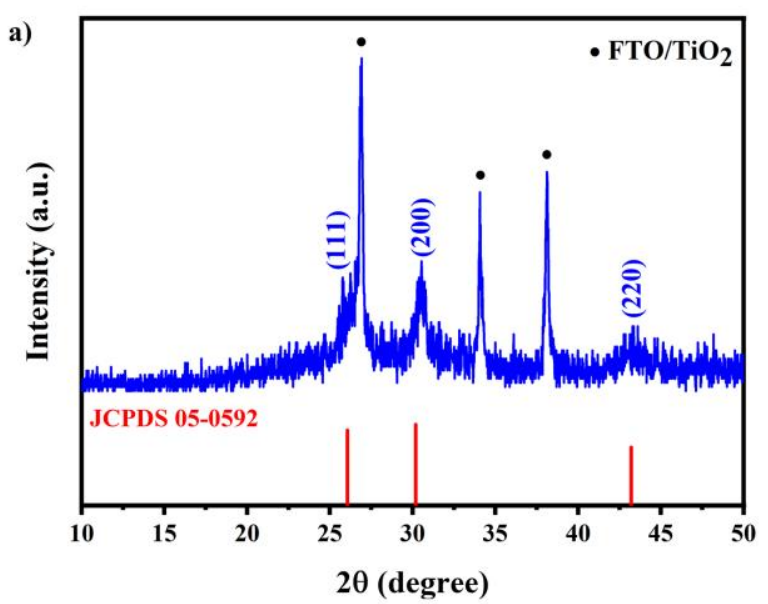

b)
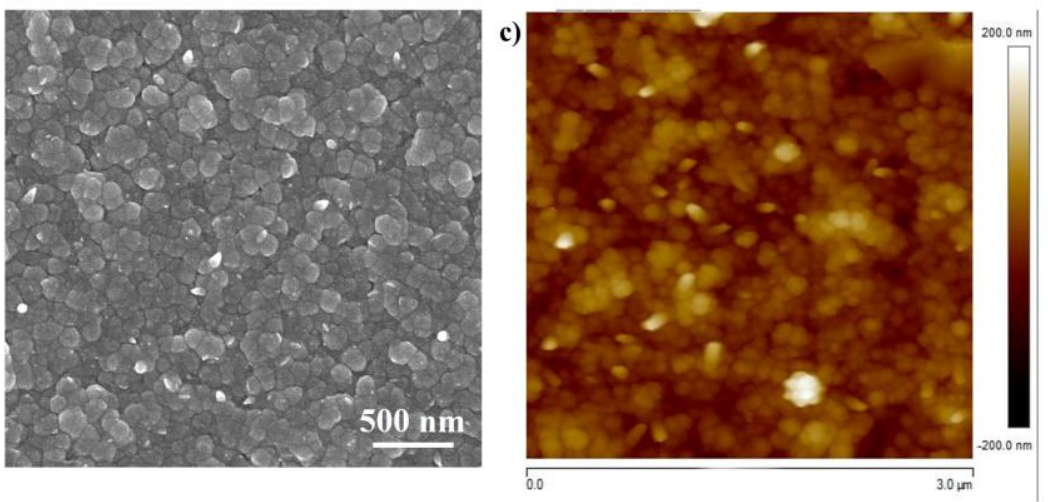

d)

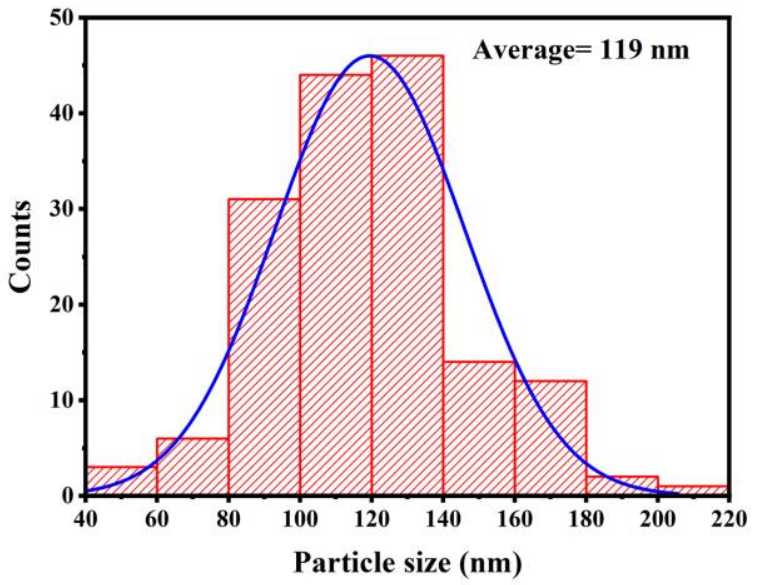

\section{Figure 1.}

Structural and morphological characterization of chemically deposited PbS film. a) XRD diffraction pattern b) surface SEM image c) AFM image and d) grain size distribution histogram. 
The position of the main Bragg diffraction peaks are the same for two $\mathrm{PbI}_{2}$ films achieved at the two temperatures. However, there are some difference in the intensity of the peaks related to $\mathrm{PbI}_{2}$ crystallite planes, depending on the temperature of the reaction. The XRD pattern of $120^{\circ} \mathrm{C}-\mathrm{PbI}_{2}$ represented almost all the characteristic peaks of $\mathrm{PbI}_{2}$, including (001), (100), (101), (102), (003), (110), (111), (103) and (201) reflections. Whereas the pattern of $155^{\circ} \mathrm{C}-\mathrm{PbI}_{2}$ revealed four major peaks of (001), (100), (110) and (111). Analysis of the preferred orientation is performed through calculation of texture coefficients. Table 1 shows the $T C(h k l)$ s the observed planes. For the $120^{\circ} \mathrm{C}-\mathrm{PbI}_{2},(001)$ plane has the highest $T C(h k l)$ value. While for $155^{\circ} \mathrm{C}-\mathrm{PbI}_{2}$ the (100) plane is dominant. The change in crystallographic direction vs the temperature of substrate is in agreement with results observed in vapor-deposited $\mathrm{PbI}_{2}$ crystals ${ }^{46}$. Since XRD diffractometer collects reflections only from the crystallographic planes parallel to substrate, so we expect this variation can be originated from the difference in microstructure features.

Figure 3a,b show the $\mathrm{SEM}$ micrographs of $\mathrm{PbI}_{2}$ films prepared at 120 and $155^{\circ} \mathrm{C}$, respectively. $\mathrm{PbI}_{2}$ layers fabricated by the our present method exhibit clearly grain boundaries and incompact structure, different from the $\mathrm{PbI}_{2}$ layers fabricated by conventional spin coating method which have fuzzy domain boundaries and few grain boundaries.

Furthermore, as expected from $\mathrm{XRD}$ results, there is obvious difference amongst the structure of $\mathrm{PbI}_{2}$ layers obtained at two different temperatures. As can be seen from Figure 3a, $120^{\circ} \mathrm{C}-\mathrm{PbI}_{2}$ has platelet crystals with hexagonal shape which are lying parallel to substrate. This structure is consistent with the calculated TC values. According to TC results shown in Table 1, for $120^{\circ} \mathrm{C}-\mathrm{PbI}_{2}$, the preferred orientation is in the (001) plane that is perpendicular to c-axis in hexagonal crystal system. So, this $\mathrm{PbI}_{2}$ develops a layered structure with basal planes parallel to substrate. on the other hand, in the case of $155^{\circ} \mathrm{C}$ - $\mathrm{PbI}_{2}$, highest TC is for (100) plane which is parallel to c-axis of hexagonal crystal. Accordingly, as can be seen from Figure 3b, lots of the plate-like grains are positioned perpendicular to the substrate. This special orientation causes the formation of lots of voids in-between which accounts for the observed 
porous $\mathrm{PbI}_{2}$ layer. The AFM images of aforementioned $\mathrm{PbI}_{2}$ films are also taken and presented at Figure 3c,d, respectively. The AFM images certifies the same morphology for achieved films.

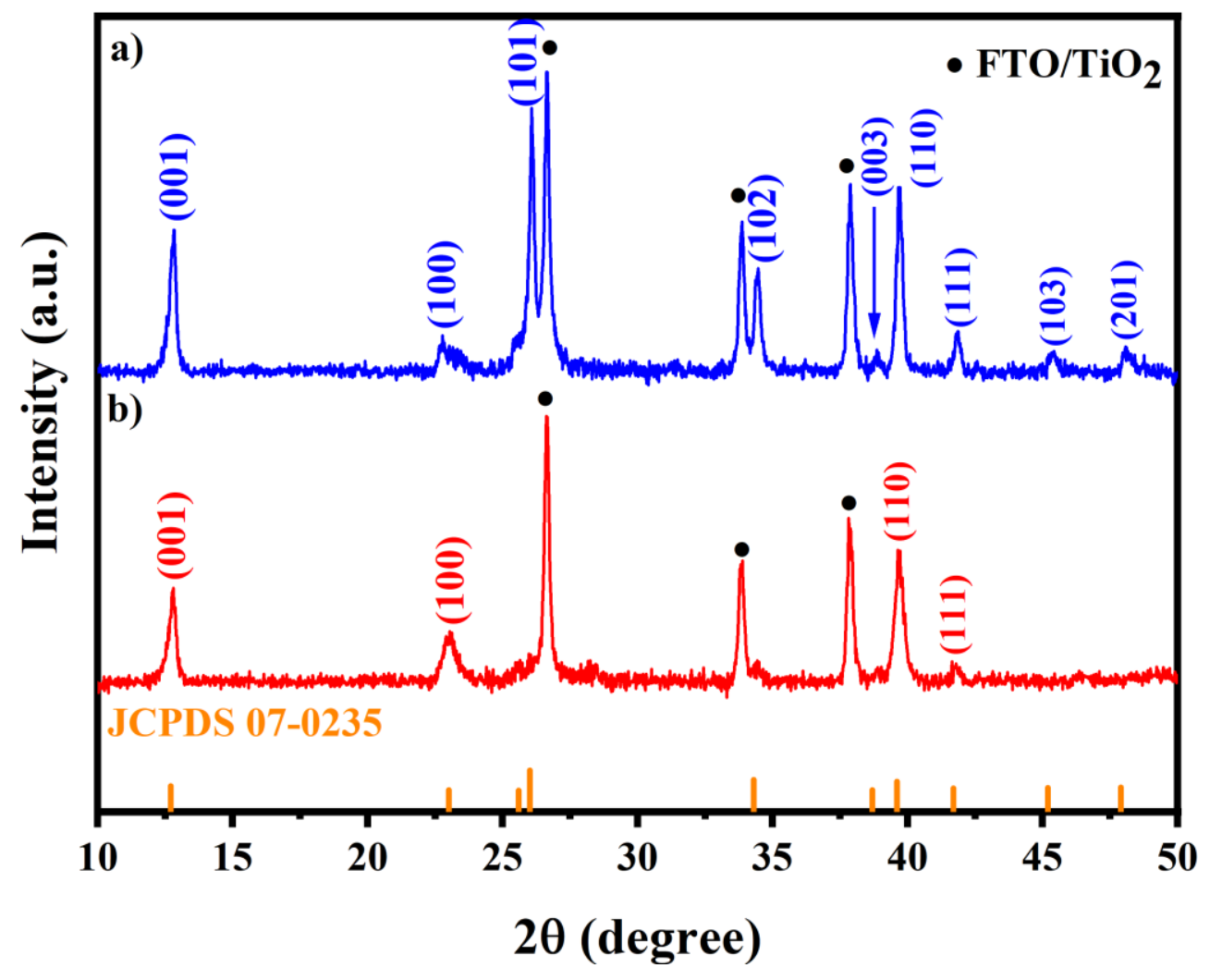

Figure 2.

XRD patterns of $\mathrm{PbI}_{2}$ films obtained from iodination of chemically deposited $\mathrm{PbS}$ films at a) 120 and b) $155^{\circ} \mathrm{C}$. 
a)

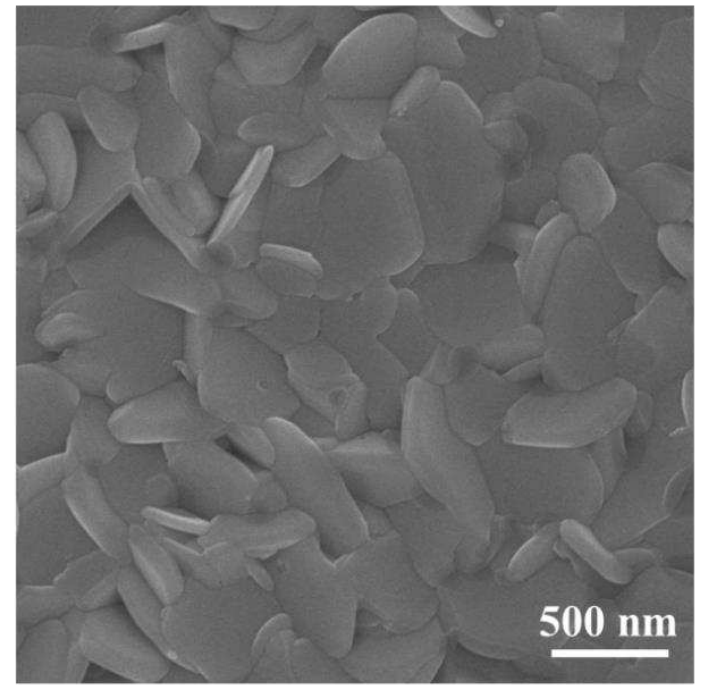

c)

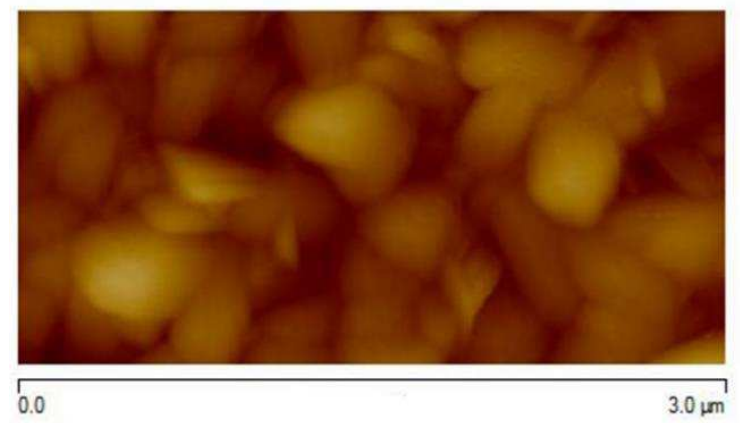

b)

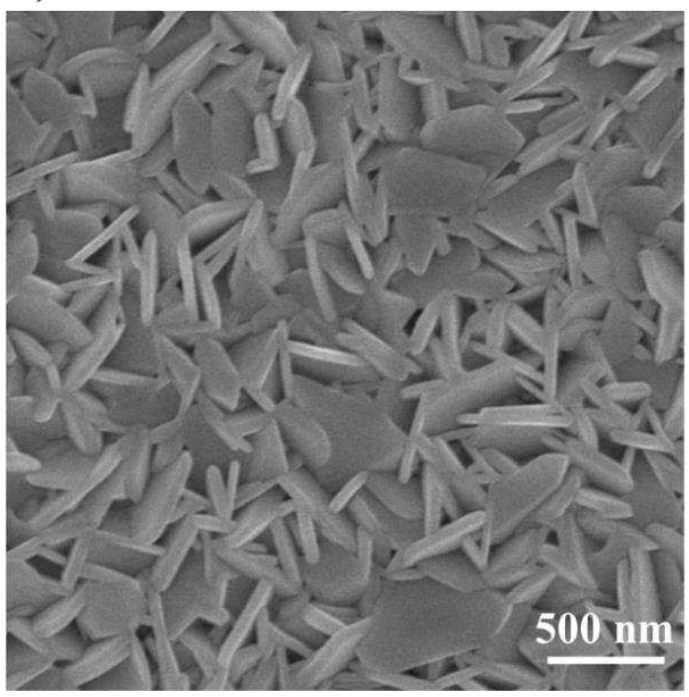

d)

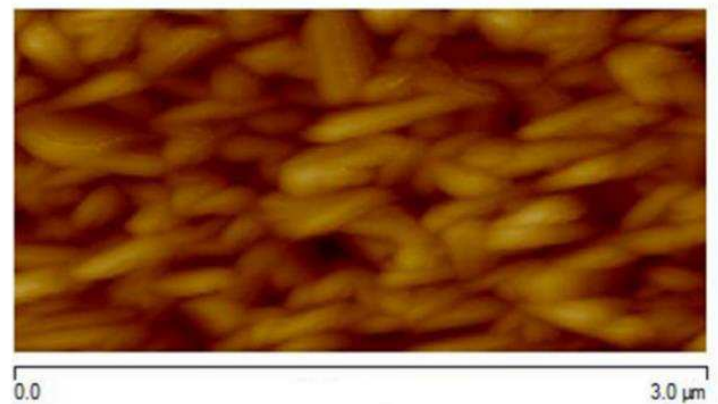

$-200.0 \mathrm{~nm}$

Figure 3.

Top surface $\mathrm{SEM}$ images and AFM images of $\mathrm{PbI}_{2}$ films obtained from iodination of chemically deposited $\mathrm{PbS}$ films at a,c) 120 and $\mathrm{b}, \mathrm{d}) 155^{\circ} \mathrm{C}$.

\section{Production of final mixed-cation mixed halide perovskite films}

It has been well demonstrated that changing the morphology of $\mathrm{PbI}_{2}$ film will provide a chance to modify the morphology and quality of perovskite layer, which may influence the PSC device performance ${ }^{47}$. In this regard, we have investigated the effect of two different $\mathrm{PbI}_{2}$ films on the solar cell properties. 
Perovskite active layers were formed by spin coating of a solution of FAI:MACl:MABr (85:10:10 mg in 1 $\mathrm{ml}$ IPA) on top of as-converted $\mathrm{PbI}_{2}$ layers on $\mathrm{mp}-\mathrm{TiO}_{2} / \mathrm{bl}-\mathrm{TiO}_{2} / \mathrm{FTO}$.

As shown in Figure 4a,b, the composition of the perovskite films achieved after iodination of $120^{\circ} \mathrm{C}-\mathrm{PbI}_{2}$ and $155^{\circ} \mathrm{C}-\mathrm{PbI}_{2}$ were characterized by $\mathrm{XRD}$. After the third step, the presence of XRD peaks at $2 \theta=$ $14.16^{\circ}, 20.04^{\circ}, 24.6^{\circ}, 28.36^{\circ}, 31.8^{\circ}, 34.92^{\circ}, 40.52^{\circ}$ and $43^{\circ}$, corresponding to the reflections from (111), (012), (021), (222), (123), (030), (024) and (333) planes of $\alpha$-phase perovskite ${ }^{48}$, respectively, supports the formation of perovskite structure. Meanwhile, there is no trace of XRD peaks of $\delta$-phase at $11.6^{\circ}$, indicating that selected composition and method is conducive to achieve desirable $\alpha$-phase perovskite. For perovskite film prepared from $120^{\circ} \mathrm{C}-\mathrm{PbI}_{2}$ an additional peak at $12.8^{\circ}$ corresponding to (001) lattice plane of $\mathrm{PbI}_{2}$ suggests the incomplete conversion to perovskite. By contrast, in the case of perovskite from $155^{\circ} \mathrm{C}-\mathrm{PbI}_{2}$, the peaks of $\mathrm{PbI}_{2}$ completely disappears, indicating the complete conversion into photoactive black phase. In addition, for former perovskite all the peaks are enhanced in intensity than those of latter perovskite. It means that modifying the precursor $\mathrm{PbI}_{2}$ morphology may also increase the crystallinity of final perovskite film.

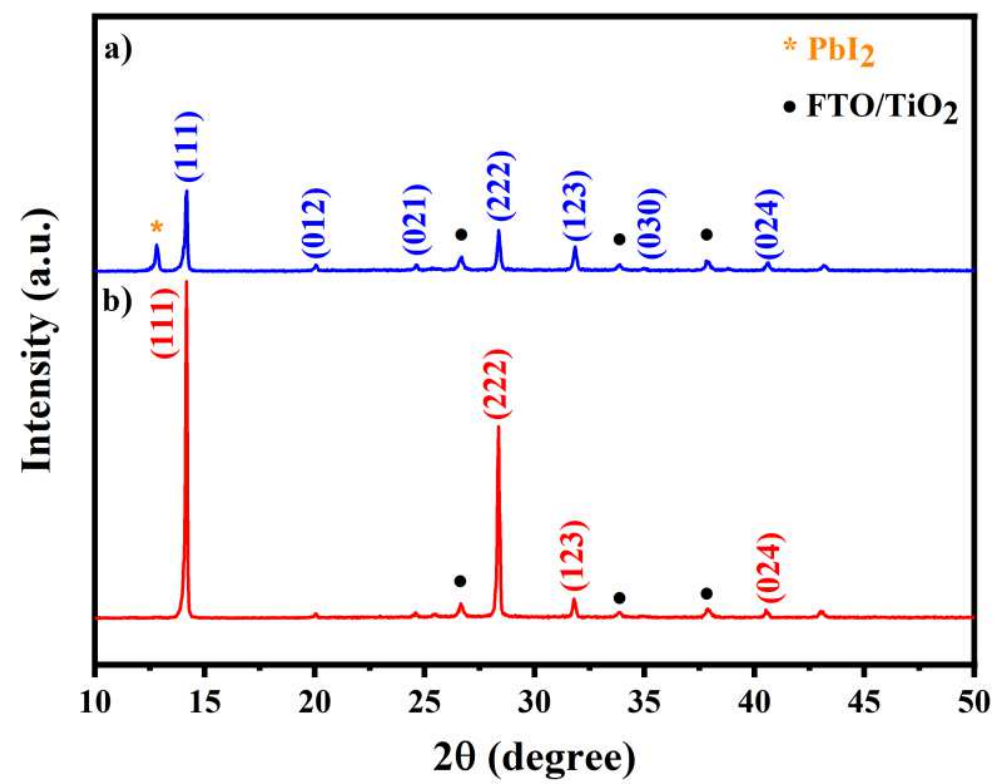

Figure 4.

XRD patterns of perovskite films converted from a) $120^{\circ} \mathrm{C}-\mathrm{PbI}_{2}$ and b) $155^{\circ} \mathrm{C}-\mathrm{PbI}_{2}$. 
The SEM images taken from the top surface of the final perovskite films, made from $\mathrm{PbI}_{2}$ layer converted at two temperatures of 120 and $155^{\circ} \mathrm{C}$, are shown in Figure 5a,b, respectively. The perovskite film produced from the $120^{\circ} \mathrm{C}-\mathrm{PbI}_{2}$ layer exhibits the existence of disconnected grains with edges which may be unconverted $\mathrm{PbI}_{2}$ since heavy-atom regions appear with brighter contrast in the SEM images ${ }^{49}$. EDX analysis of the white regions also confirms the speculated composition, (Figure S1). In contrast, the perovskite film produced from the $155^{\circ} \mathrm{C}-\mathrm{PbI}_{2}$ layer shows smooth and homogenous perovskite grains with sizes up to $800 \mathrm{~nm}$ which is comparable to that observed for perovskite films prepared by a conventional spin-coating method ${ }^{50}$. Furthermore some spiral form lines can be seen on grains. According to the theory of crystal growth, it can be the result of spiral growth mechanism which leads to an step-like morphology ${ }^{51}$.
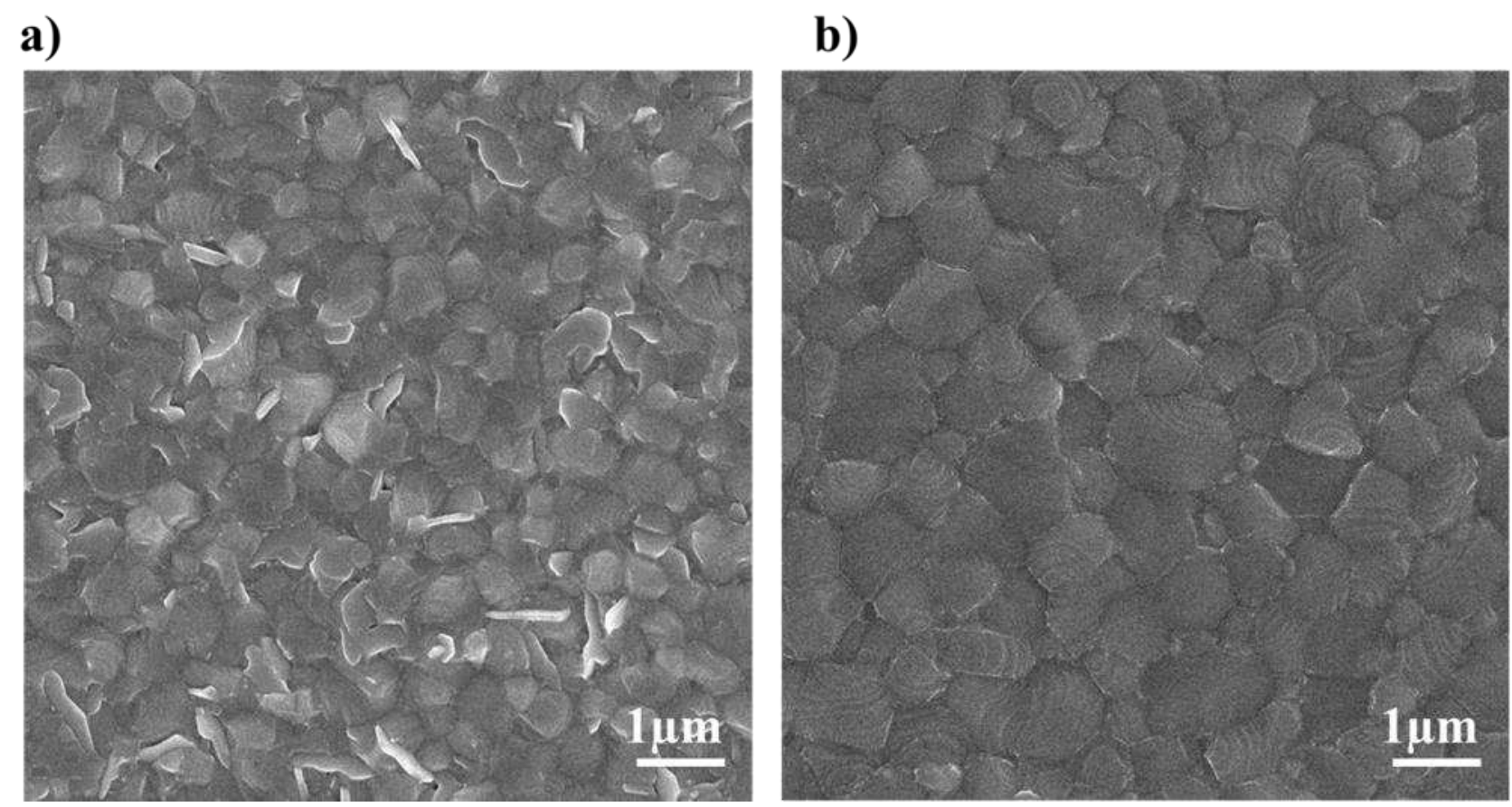

Figure 5.

SEM images of perovskite films converted from a) $120^{\circ} \mathrm{C}-\mathrm{PbI}_{2}$ and b) $155^{\circ} \mathrm{C}-\mathrm{PbI}_{2}$. 
According to both XRD and SEM results, it can be concluded that the reaction rate of $155^{\circ} \mathrm{C}-\mathrm{PbI}_{2}$ is faster than that of $120^{\circ} \mathrm{C}-\mathrm{PbI}_{2}$. In the case of $155^{\circ} \mathrm{C}-\mathrm{PbI}_{2}$, the vertically arranged nanoplates create a large degree of porosity on the surface of $\mathrm{PbI}_{2}$ film. These pores facilitates the permeation of FAI:MACl:MABr solution in the whole $\mathrm{pbI}_{2}$ layer, which in turn would favor the full conversion of $\mathrm{PbI}_{2}$ to final perovskite material. Fast conversion is of great importance in sequential deposition process because remnant $\mathrm{PbI}_{2}$ can act as an insulate layer.

Cross sectional SEM images of layer after each step is provided in Figure 6. Comparing the Figure 6a and $\mathrm{b}$ it can be seen that the thickness value of $\mathrm{PbI}_{2}$ is almost twice of $\mathrm{PbS}$. According to Figure $\mathbf{6 c}$ the thickness of $\mathrm{FAPbI}_{3}$-based perovskite after converting $\mathrm{PbI}_{2}$ increased by a factor of 2 again. We interpret the thickening of the deposited films by the volume expansion happening after chemical conversion at each step ${ }^{20,26}$. The volume expansion is attributed to variation of lattice parameters of $\mathrm{PbS}, \mathrm{PbI}_{2}$ and perovskite.

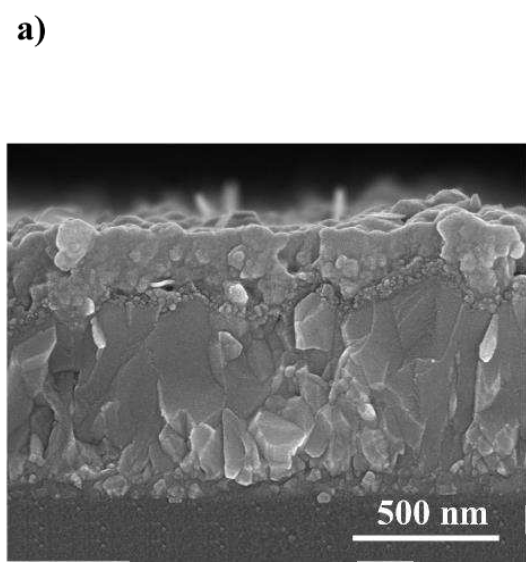

b)

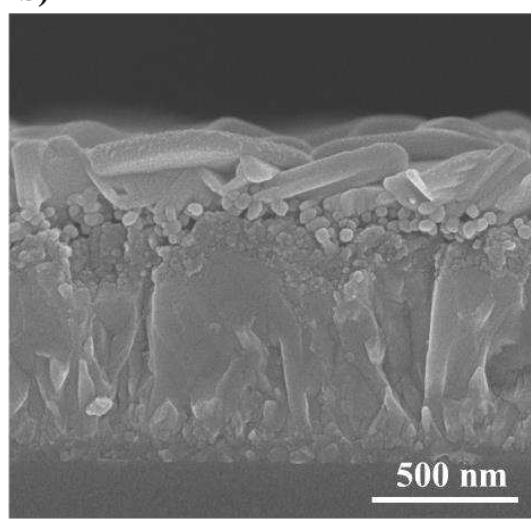

c)

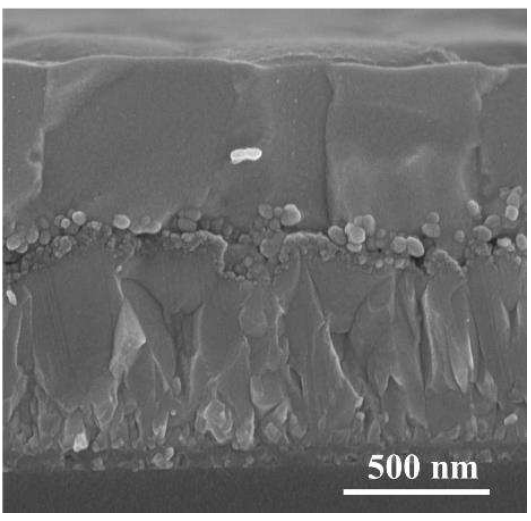

\section{Figure 6.}

Cross sectional SEM image of a) $\mathrm{PbS}$, b) $\mathrm{PbI}_{2}$ and c) $\mathrm{FAPbI}_{3}$-based films on mp-TiO $/$ bl-TiO $/ \mathrm{FTO}$ substrate obtained after each step of multi-step chemical bath deposition assisted synthesis of halide perovskite film.

Figure 7 shows the UV absorption spectra of two samples prepared from two different $\mathrm{PbI}_{2}$ layers. Both spectra show onsets of absorption at $810 \mathrm{~nm}$. The optical band gap almost remains the same $(1.55 \mathrm{eV})$ for 
both films. The higher absorption of perovskite film based on $155^{\circ} \mathrm{C}-\mathrm{PbI}_{2}$ compared to perovskite film based on $120^{\circ} \mathrm{C}-\mathrm{PbI}_{2}$ might be correlated to the higher amount of perovskite in former one.

$\mathrm{UV}$ absorption spectra also confirm the formation of $\alpha$-phase of $\mathrm{FAPbI}_{3}$ without any trace of $\delta$-phase. Because yellow phase of $\mathrm{FAPbI}_{3}$ has characteristic absorption peak below $500 \mathrm{~nm}$, whereas the both obtained spectra have shown a remarkable absorption in the visible range ${ }^{52}$.

Obtaining pure $\alpha$-phase of $\mathrm{FAPbI}_{3}$ is of great importance for photovoltaic applications. The yellow $\delta-\mathrm{FAPbI}_{3}$, is a non-photoactive phase and due to having a chain-like structure prevents the transport of electrons and in turn reduces photovoltaic performance ${ }^{53}$.

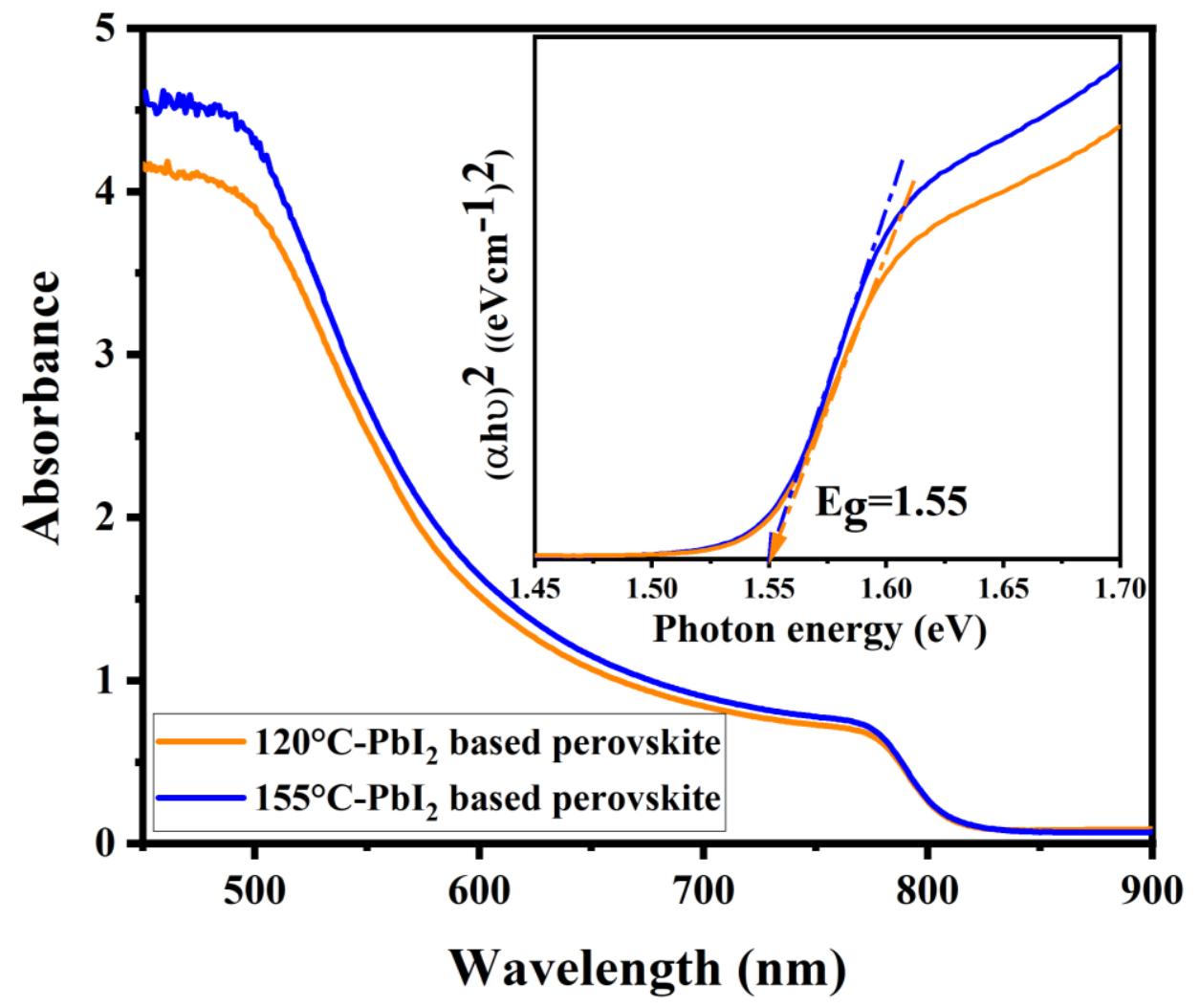

Figure 7.

Absorption spectrum for the $\mathrm{FAPbI}_{3}$-based films produced from $120^{\circ} \mathrm{C}-\mathrm{PbI}_{2}$ and $155^{\circ} \mathrm{C}-\mathrm{PbI}_{2}$. 
PSC fabrication and device performance

In order to investigate the photovoltaic applicability of the synthesized perovskite films, devices with

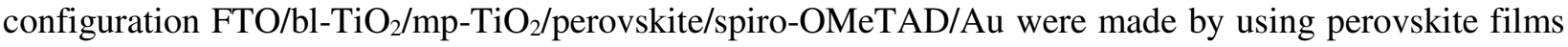
obtained from three-step-method. Figure 8a shows the cross sectional view of the complete perovskite cell and the right part of image was colored and labeled to make a guide to position and thickness of each layer. It can be seen that perovskite film prepared by multi-step method has a columnar crystal grains which are elongated from bottom to top.

The related current density-voltage (J-V) curves of the best perovskite fabricated from perovskite based on $120^{\circ} \mathrm{C}-\mathrm{PbI}_{2}$ and $155^{\circ} \mathrm{C}-\mathrm{PbI}_{2}$ measured under $\mathrm{AM} 1.5 \mathrm{G}$ solar illumination at $100 \mathrm{~mW} \mathrm{~cm} \mathrm{~cm}^{-2}$ and are plotted in Figure 8 b. Also Table 2 summarizes the photovoltaic parameters obtained from j-V curves, average values and corresponding standard deviation. Tables S3 and S4 in the supplementary document shows photovoltaic parameters and error analysis derived from $\mathrm{J}-\mathrm{V}$ curves of devices. As can be seen from Table 2, the best-performing cell fabricated via proposed method, demonstrates acceptable performance with a $J_{s c}$ of $21.43 \mathrm{~mA} \mathrm{~cm}{ }^{-2}, V_{o c}$ of $0.918 \mathrm{~V}, F F$ of 57.67 and $P C E$ of $11.35 \%$. It can be seen that the $J_{s c}$ of PSC based on $155^{\circ} \mathrm{C}-\mathrm{PbI}_{2}$ increased slightly compared that of $120^{\circ} \mathrm{C}-\mathrm{PbI}_{2}$ based perovskite. It can be related to $\mathrm{PbI}_{2}$-free and high crystalline perovskite synthesized from $155^{\circ} \mathrm{C}-\mathrm{PbI}_{2}$ which leads to increment of visible light absorption. Furthermore, in the device based on $120^{\circ} \mathrm{C}-\mathrm{PbI}_{2}$, the leftover $\mathrm{PbI}_{2}$ can hinder the electron transfer of perovskite film due to high resistivity of $\mathrm{PbI}_{2}$ which in turn increases the possibility of charge carrier recombination and reduces $V_{o c}$ and $F F$.

Totally, the performance of the device prepared by proposed three-step method is comparable with the performance of other devices made from uncommon metal precursor rather than $\mathrm{PbI}_{2}$ and is the highest reported efficiency for CBD-based method of synthesizing perovskite. Nevertheless, the method is still less efficient compare to the conventional spin coating method and there are many rooms to modify different parameters of this method in order to enhancement of efficiency. 
a)

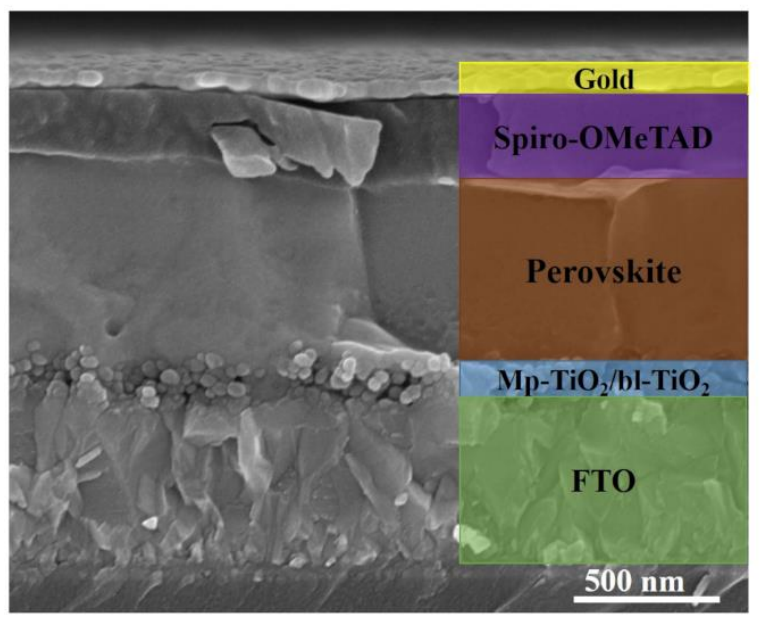

b)

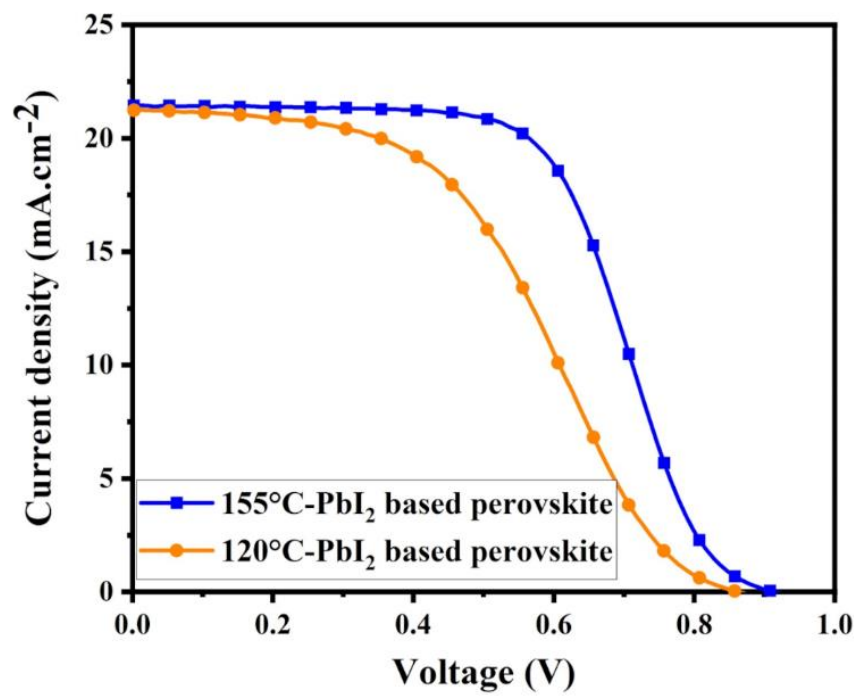

\section{Figure 8}

(a) Cross section $\mathrm{SEM}$ image of a $\mathrm{FTO} / \mathrm{bl}-\mathrm{TiO}_{2} / \mathrm{mp}-\mathrm{TiO}_{2} /$ perovskite/Spiro-OMeTAD/Au solar cell. b) Current-voltage characteristic of the best-performance devices based on $120^{\circ} \mathrm{C}-\mathrm{PbI}_{2}$ and $155^{\circ} \mathrm{C}-\mathrm{PbI}_{2}$.

\section{Conclusion}

Briefly, a scalable and environmentally friendly route was developed by using chemically deposited $\mathrm{PbS}$ from an aqueous solution as the precursor and created perovskite films with good quality and full coverage. The iodination temperature in second step was changed in a controlled way and the influence on final film quality was evaluated. Finally, well grown perovskite films with no unconverted $\mathrm{PbI}_{2}$ had successfully synthesized by iodination the $\mathrm{PbS}$ layer at $155^{\circ} \mathrm{C}$ and exposing to the FAI:MACl:MABr/IPA solution which subsequently have been applied in solar cells with the following structure: FTO/bl$\mathrm{TiO}_{2} / \mathrm{mp}-\mathrm{TiO}_{2} /$ perovskite/spiro-OMeTAD/ Au. The assembled solar cells represented the PCE of $11.35 \%$ with corresponding photocurrent of $21.43 \mathrm{~mA} \mathrm{~cm}^{-2}$ and open circuit voltage of $0.918 \mathrm{~V}$. CBD is a widely used industrial method, so the offered technique opens new avenue for large scale production of perovskite solar cells. Moreover, avoiding the use of toxic solvent especially DMF facilitates the green 
fabrication of PSCs. It can be expected that the performance of devices made by this method will be enhanced via optimizing the various parameters of the deposition.

\section{Materials and method}

Preparation of electron transport layers- Fluorine-doped tin oxide (FTO) substrates (Pilkington, TEC8, 8

$\Omega \mathrm{cm}^{-2}$ ) were undergone surface preparation including pattern etching and ultrasonically cleaning in acetone, detergent and ethanol for 30 min per each. A dense $\mathrm{TiO}_{2}$ blocking layer $\left(\mathrm{bl}-\mathrm{TiO}_{2}\right)$ was deposited on the FTO via the spray pyrolysis method from a solution of titanium diisopropoxide bis(acetylacetonate) (Aldrich) diluted in ethanol $(\mathrm{v} / \mathrm{v}, 1 / 10)$ at $450^{\circ} \mathrm{C}$. Then, a 200 -nm thick mesoporous $\mathrm{TiO}_{2}\left(\mathrm{mp}-\mathrm{TiO}_{2}\right)$ layer was fabricated on the substrates by spin coating a $\mathrm{TiO}_{2}$ commercial paste (containing $\mathrm{TiO}_{2}$ nanoparticles: average diameter: $50 \mathrm{~nm}$, anatase) diluted in 2-methoxyethanol and terpineol (Aldrich) solution followed by annealing at $500^{\circ} \mathrm{C}$ for $60 \mathrm{~min}$ and cooling to room temperature.

Synthesizing of the perovskite film- a three-step deposition method was employed to produce the perovskite film. Initially a $\mathrm{PbS}$ layer was coated on substrates via chemical bath deposition method. The deposition bath contained $85 \mathrm{ml}$ of an aqueous solution, consisting of $2.5 \mathrm{ml} \mathrm{Pb}\left(\mathrm{CH}_{3} \mathrm{COO}\right)_{2} \cdot 3 \mathrm{H}_{2} \mathrm{O}(\mathrm{Sigma}-$ Aldrich) $1 \mathrm{M}, 6 \mathrm{ml}$ thiourea $\mathrm{SC}\left(\mathrm{NH}_{2}\right)_{2}$ (Sigma-Aldrich) $1 \mathrm{M}, 10 \mathrm{ml} \mathrm{NaOH}$ (Aldrich) $1 \mathrm{M}$ and $2 \mathrm{ml}$ triethanolamine (Sigma) $1 \mathrm{M}$. The deposition was performed at room temperature. Afterward, the $\mathrm{PbS}$ layers and iodine chips (Sigma-Aldrich) were put inside one petri dish on different temperatures to chemically convert $\mathrm{PbS}$ to $\mathrm{PbI}_{2}$. Next, $\mathrm{PbI}_{2}$ films were exposed to a FAI:MACl:MABr solution (85:10:10 $\mathrm{mg} \mathrm{ml}^{-1}$ ) and then spun at $5000 \mathrm{rpm}$ for $30 \mathrm{~s}$. The selection of solution was based on a comparison between the qualities of perovskite films obtained by different solutions as shown in Figure S2. After two step annealing at $150^{\circ} \mathrm{C}$ and $100^{\circ} \mathrm{C}$ for 30 min per each, the conversion of $\mathrm{PbI}_{2}$ to perovskite film was completed.

Assembling perovskite solar cells (PSCs)- After preparing $\mathrm{FAPbI}_{3}$-based perovskite/ mp- $\mathrm{TiO}_{2} / \mathrm{bl}_{-} \mathrm{TiO}_{2}$, a 2,20, 7,70-tetrakis (N,N-di-pmethoxyphenylamino)-9,90 - spirobifluorene (spiro - OMeTAD, Lumtec) 
processor solution (100 mg of spiro-OMeTAD, $39 \mathrm{ml}$ of 4-tert-butylpyridine (Aldrich), $23 \mathrm{ml}$ of bis (trifluoromethane) sulfonamide lithium salt (Li-TFSI, Aldrich) solution and $10 \mathrm{ml}$ of cobalt salt (Lumtec) solution per $1.1 \mathrm{ml}$ chlorobenzene) was spin coated onto the as-deposited perovskite film described above at $3000 \mathrm{rpm}$ for $30 \mathrm{~s}$. Finally, for completing the device an $80 \mathrm{~nm}$ gold film was coated on top of layers through thermal evaporation method.

Characterization-The thickness of the deposited and chemically converted solid state thin films were measured by a stylus profiler (KLA Tencor). The morphologies of the films were examined using a scanning electron microscopy (SEM, S-4800, Hitach High-Technologies) and atomic force microscopy (AFM, MultiMode V Veeco). Energy dispersive X-ray analysis (EDX) is done in conjunction with SEM. Crystalline structure of the films were determined by using a X-ray diffractometer (XRD, D8 ADVANCE, Bruker AXS) with $\mathrm{Cu} \mathrm{K} \alpha$ radiation $(\lambda=1.5405 \AA)$.

In order to estimate the degree of crystalline orientation in different directions, the texture coefficient (TC) was calculated by Equation $6^{46}$ :

$T C(h k l)=\frac{I(h k l) / I_{0}(h k l)}{\left[\sum I(h k l) / I_{0}(h k l)\right] / N}$

Where $I(h k l)$ is the intensity of measured peak, $I_{o}(h k l)$ is the intensity of reference data peak for random oriented powder, and $\mathrm{N}$ is the number of measured peaks.

The absorption spectrum of final perovskite layers was extracted using a UV-vis spectrophotometer (Jasco V-780). In order to record current-voltage (J-V) graphs, A Keithley 2400 source meter was used and Illumination of air mass (AM) $1.5 \mathrm{G}$ and a power of $100 \mathrm{~mW} \mathrm{~cm}$ was applied by a solar simulator (Newport, Oriel Class A, 91195A). For setting the correct irradiance of solar simulator, a calibrated Si reference cell certified by National Renewable Energy Laboratory (NREL) was used. 


\section{References}

1. Li, Z. et al. Scalable fabrication of perovskite solar cells. Nat. Rev. Mater. 3, 1-20 (2018).

2. De Wolf, S. et al. Organometallic halide perovskites: sharp optical absorption edge and its relation to photovoltaic performance. J. Phys. Chem. Lett. 5, 1035-1039 (2014).

3. Lin, Q., Armin, A., Nagiri, R. C. R., Burn, P. L. \& Meredith, P. Electro-optics of perovskite solar cells. Nat. Photonics 9, 106 (2015).

4. Sun, S. et al. The origin of high efficiency in low-temperature solution-processable bilayer organometal halide hybrid solar cells. Energy Environ. Sci. 7, 399-407 (2014).

5. Tao, S. X., Cao, X. \& Bobbert, P. A. Accurate and efficient band gap predictions of metal halide perovskites using the DFT-1/2 method: GW accuracy with DFT expense. Sci. Rep. 7, 1-9 (2017).

6. Xing, G. et al. Long-range balanced electron-and hole-transport lengths in organic-inorganic $\mathrm{CH}_{3} \mathrm{NH}_{3} \mathrm{PbI}_{3}$. Science 342, 344-347 (2013).

7. Kojima, A., Teshima, K., Shirai, Y. \& Miyasaka, T. Organometal halide perovskites as visiblelight sensitizers for photovoltaic cells. J. Am. Chem. Soc. 131, 6050-6051 (2009).

8. Huang, F., Li, M., Siffalovic, P., Cao, G. \& Tian, J. From scalable solution fabrication of perovskite films towards commercialization of solar cells. Energy Environ. Sci. 12, 518-549 (2019).

9. Zhang, Y.-N., Li, B., Fu, L. \& Yin, L.-W. One-step-spin-coating route for homogeneous perovskite/pyrrole-C60 fullerene bulk heterojunction for high performance solar cells. J. Power Sources 419, 27-34 (2019).

10. Uličná, S. et al. Scalable deposition of high-efficiency perovskite solar cells by spray-coating. ACS Appl. Energy Mater. 1, 1853-1857 (2018). 
11. Zhong, Y. et al. Blade-coated hybrid perovskite solar cells with efficiency>17\%: an in situ investigation. ACS Energy Lett. 3, 1078-1085 (2018).

12. Li, S.-G. et al. Inkjet printing of $\mathrm{CH}_{3} \mathrm{NH}_{3} \mathrm{PbI}_{3}$ on a mesoscopic $\mathrm{TiO} 2 \mathrm{film}$ for highly efficient perovskite solar cells. J. Mater. Chem. A 3, 9092-9097 (2015).

13. Cotella, G. et al. One-step deposition by slot-die coating of mixed lead halide perovskite for photovoltaic applications. Sol. Energy Mater. Sol. Cells 159, 362-369 (2017).

14. Burschka, J. et al. Sequential deposition as a route to high-performance perovskite-sensitized solar cells. Nature 499, 316-319 (2013).

15. Chen, Q. et al. Planar heterojunction perovskite solar cells via vapor-assisted solution process. J. Am. Chem. Soc. 136, 622-625 (2014).

16. He, Y. et al. Using elemental $\mathrm{Pb}$ surface as a precursor to fabricate large area $\mathrm{CH}_{3} \mathrm{NH}_{3} \mathrm{PbI}_{3}$ perovskite solar cells. Appl. Surf. Sci. 389, 540-546 (2016).

17. Cui, X.-P. et al. Electrodeposition of $\mathrm{PbO}$ and its in situ conversion to $\mathrm{CH}_{3} \mathrm{NH}_{3} \mathrm{PbI}_{3}$ for mesoscopic perovskite solar cells. Chem. Commun. 51, 1457-1460 (2015).

18. Huang, J. et al. Direct conversion of $\mathrm{CH}_{3} \mathrm{NH}_{3} \mathrm{PbI}_{3}$ from electrodeposited $\mathrm{PbO}$ for highly efficient planar perovskite solar cells. Sci. Rep. 5, 15889 (2015).

19. Popov, G., Mattinen, M., Kemell, M. L., Ritala, M. \& Leskelä, M. Scalable route to the fabrication of $\mathrm{CH}_{3} \mathrm{NH}_{3} \mathrm{PbI}_{3}$ perovskite thin films by electrodeposition and vapor conversion. ACS omega 1, 1296-1306 (2016).

20. Chen, H., Wei, Z., Zheng, X. \& Yang, S. A scalable electrodeposition route to the low-cost, versatile and controllable fabrication of perovskite solar cells. Nano Energy 15, 216-226 (2015).

21. Feng, Y. et al. Solution-processed perovskite solar cells using environmentally friendly solvent system. Thin Solid Films 636, 639-643 (2017). 
22. Shinde, D. V et al. Enhanced efficiency and stability of an aqueous lead-nitrate-based organometallic perovskite solar cell. ACS Appl. Mater. Interfaces 9, 14023-14030 (2017).

23. Hsieh, T.-Y., Wei, T.-C., Wu, K.-L., Ikegami, M. \& Miyasaka, T. Efficient perovskite solar cells fabricated using an aqueous lead nitrate precursor. Chem. Commun. 51, 13294-13297 (2015).

24. Adnan, M. \& Lee, J. K. All sequential dip-coating processed perovskite layers from an aqueous lead precursor for high efficiency perovskite solar cells. Sci. Rep. 8, 1-10 (2018).

25. Qiu, J., McDowell, L. L. \& Shi, Z. Room-temperature cubic perovskite thin films by three-step all-vapor conversion from PbSe to $\mathrm{MAPbI}_{3}$. Cryst. Growth Des. 19, 2001-2009 (2019).

26. Sutherland, B. R. et al. Perovskite thin films via atomic layer deposition. Adv. Mater. 27, 53-58 (2015).

27. da Silva Filho, J. M. C., Ermakov, V. A. \& Marques, F. C. Perovskite thin film synthesised from sputtered lead sulphide. Sci. Rep. 8, 1-8 (2018).

28. Luo, P. et al. A novel transformation route from $\mathrm{PbS}$ to $\mathrm{CH}_{3} \mathrm{NH}_{3} \mathrm{PbI}_{3}$ for fabricating curved and large-area perovskite films. Chem. Commun. 52, 11203-11206 (2016).

29. Gozalzadeh, S., Nasirpouri, F. \& Seok, S. Il. Dimethylformamide-free synthesis and fabrication of lead halide perovskite solar cells from electrodeposited PbS precursor films. Chem. Eng. J. 128460.

30. Krane, K. S. Modern physics. (John Wiley \& Sons, 2019).

31. Singh, B. P., Kumar, R., Kumar, A. \& Tyagi, R. C. Vacuum deposition of stoichiometric crystalline PbS films: the effect of sulfurizing environment during deposition. Mater. Res. Express 2 , 106401 (2015).

32. Rosario, S. R. et al. Ag-doped PbS thin films by nebulizer spray pyrolysis for solar cells. Int. J. Energy Res. 44, 4505-4515 (2020). 
33. Preetha, K. C., Murali, K. V, Ragina, A. J., Deepa, K. \& Remadevi, T. L. Effect of cationic precursor $\mathrm{pH}$ on optical and transport properties of SILAR deposited nano crystalline $\mathrm{PbS}$ thin films. Curr. Appl. Phys. 12, 53-59 (2012).

34. Alanyalioğlu, M., Bayrakçeken, F. \& Demir, Ü. Preparation of PbS thin films: A new electrochemical route for underpotential deposition. Electrochim. Acta 54, 6554-6559 (2009).

35. Levchenko, V. I. et al. Heteroepitaxy of PbS on porous silicon. Thin Solid Films 348, 141-144 (1999).

36. Yücel, E. \& Yücel, Y. Fabrication and characterization of Sr-doped PbS thin films grown by CBD. Ceram. Int. 43, 407-413 (2017).

37. Zheng, X. et al. Cu-doped $\mathrm{PbS}$ thin films with low resistivity prepared via chemical bath deposition. Mater. Lett. 167, 128-130 (2016).

38. Pradhan, J. et al. Two-Dimensional Hybrid Organohalide Perovskites from Ultrathin PbS Nanocrystals as Template. J. Phys. Chem. C 121, 6401-6408 (2017).

39. Vorobiev, Y. V et al. The effects of porosity on optical properties of semiconductor chalcogenide films obtained by the chemical bath deposition. Nanoscale Res. Lett. 7, 1-5 (2012).

40. Hodes, G. Semiconductor and ceramic nanoparticle films deposited by chemical bath deposition. Phys. Chem. Chem. Phys. 9, 2181-2196 (2007).

41. Chauhan, S. M., Chaki, S. H., Deshpande, M. P., Tailor, J. P. \& Khimani, A. J. Characterization of CBD deposited CuInSe2 thin film. Mater. Sci. Semicond. Process. 74, 329-335 (2018).

42. Tong, S. et al. Fully-printed, flexible cesium-doped triple cation perovskite photodetector. Appl. Mater. Today 15, 389-397 (2019).

43. Chen, H. et al. Advances to High-Performance Black-Phase $\mathrm{FAPbI}_{3}$ Perovskite for Efficient and Stable Photovoltaics. Small Struct. 2000130. 
44. Navale, S. T., Bandgar, D. K., Chougule, M. A. \& Patil, V. B. Facile method of preparation of $\mathrm{PbS}$ films for $\mathrm{NO}_{2}$ detection. RSC Adv. 5, 6518-6527 (2015).

45. Bhuse, V. M., Hankare, P. P., Garadkar, K. M. \& Khomane, A. S. A simple, convenient, low temperature route to grow polycrystalline copper selenide thin films. Mater. Chem. Phys. 80, 82-88 (2003).

46. Schieber, M., Zamoshchik, N., Khakhan, O. \& Zuck, A. Structural changes during vapor-phase deposition of polycrystalline-PbI2 films. J. Cryst. Growth 310, 3168-3173 (2008).

47. So, F. World Scientific Handbook of Organic Optoelectronic Devices (Volumes 1 \& 2): Volume 1: Perovskite Electronics Volume 2: Organic Photovoltaics (OPVs). vol. 12 (World Scientific, 2018).

48. Han, Q. et al. Single crystal formamidinium lead iodide $\left(\mathrm{FAPbI}_{3}\right)$ : insight into the structural, optical, and electrical properties. Adv. Mater. 28, 2253-2258 (2016).

49. Soltanpoor, W. et al. Hybrid vapor-solution sequentially deposited mixed-halide perovskite solar cells. ACS Appl. Energy Mater. 3, 8257-8265 (2020).

50. Min, H. et al. Efficient, stable solar cells by using inherent bandgap of $\alpha$-phase formamidinium lead iodide. Science 366, 749-753 (2019).

51. Zhao, Q. et al. Improving the photovoltaic performance of perovskite solar cells with acetate. Sci. Rep. 6, 38670 (2016).

52. Li, G., Zhang, T., Xu, F. \& Zhao, Y. A facile deposition of large grain and phase pure $\alpha-\mathrm{FAPbI}_{3}$ for perovskite solar cells via a flash crystallization. Mater. Today Energy 5, 293-298 (2017).

53. Xu, X. et al. Elimination of Yellow Phase: An Effective Method to Achieve High Quality $\mathrm{HC}\left(\mathrm{NH}_{2}\right)_{2} \mathrm{PbI}_{3}$-based Perovskite Films. ChemSusChem 13, 956-963 (2020). 


\section{Author contributions}

F.N. and S.G. together conceived the research idea. F.N. initiated, conceptualized and supervised the research project. S.G. have carried out experiments. All the authors have analyzed and discussed the results thoroughly. S.G. and F.N. wrote the manuscript with inputs from S.I.S. and all authors contributed and approved the final version of the manuscript.

\section{Additional Information}

Supplementary information accompanies this paper.

Competing Interests The authors declare no competing interests.

\section{Figure legends}

Figure 1. Structural and morphological characterization of chemically deposited $\mathrm{PbS}$ film. a) XRD diffraction pattern b) surface SEM image c) AFM image and d) grain size distribution histogram.

Figure 2. XRD patterns of $\mathrm{PbI}_{2}$ films obtained from iodination of chemically deposited $\mathrm{PbS}$ films at a) 120 and b) $155^{\circ} \mathrm{C}$.

Figure 3. Top surface $\mathrm{SEM}$ images and $\mathrm{AFM}$ images of $\mathrm{PbI}_{2}$ films obtained from iodination of chemically deposited $\mathrm{PbS}$ films at a,c) 120 and b,d) $155^{\circ} \mathrm{C}$.

Figure 4. XRD patterns of perovskite films converted from a) $120^{\circ} \mathrm{C}-\mathrm{PbI}_{2}$ and b) $155^{\circ} \mathrm{C}-\mathrm{PbI}_{2}$.

Figure 5. SEM images of perovskite films converted from a) $120^{\circ} \mathrm{C}-\mathrm{PbI}_{2}$ and b) $155^{\circ} \mathrm{C}-\mathrm{PbI}_{2}$.

Figure 6. Cross sectional SEM image of a) $\mathrm{PbS}$, b) $\mathrm{PbI}_{2}$ and c) $\mathrm{FAPbI}_{3}$-based films on mp-TiO $/$ bl-

$\mathrm{TiO}_{2} /$ FTO substrate obtained after each step of multi-step chemical bath deposition assisted synthesis of halide perovskite film.

Figure 7. Absorption spectrum for the $\mathrm{FAPbI}_{3}$-based films produced from $120^{\circ} \mathrm{C}-\mathrm{PbI}_{2}$ and $155^{\circ} \mathrm{C}-\mathrm{PbI}_{2}$.

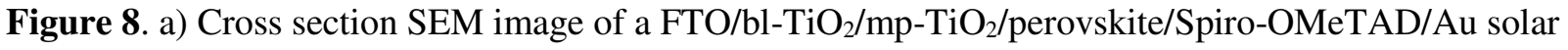


cell. b) Current-voltage characteristic of the best-performance devices based on $120^{\circ} \mathrm{C}-\mathrm{PbI}_{2}$ and $155^{\circ} \mathrm{C}$ $\mathrm{PbI}_{2}$.

\section{Tables}

Table 1. The texture coefficients in for the crystal planes of $\mathrm{PbI}_{2}$ chemically bath deposited at different temperatures.

\section{Texture Coefficient}

\begin{tabular}{lccccccccc} 
& $(001)$ & $(100)$ & $(101)$ & $(102)$ & $(003)$ & $(110)$ & $(111)$ & $(103)$ & $(201)$ \\
\hline $\mathbf{1 2 0}^{\circ} \mathbf{C}-\mathbf{P b I}_{2}$ & 2.42 & 0.62 & 0.79 & 0.80 & 0.89 & 1.53 & 1.10 & 0.52 & 0.34 \\
\hline $\mathbf{1 5 5}^{\circ} \mathbf{C}-\mathbf{P b I}_{2}$ & 0.78 & 2.39 & - & - & - & 0.58 & 0.25 & - & - \\
\hline
\end{tabular}

Table 2. Photovoltaic parameters of PSCs fabricated by chemical bath deposition-based method. The values in parentheses correspond to the average values from 6 devices and the corresponding standard deviation.

\begin{tabular}{ccccc}
\hline & $V_{o c}(\mathrm{~V})$ & $J_{s c}\left(\mathrm{~mA} \mathrm{~cm}^{-2}\right)$ & $F F(\%)$ & $P C E(\%)$ \\
\hline $120^{\circ} \mathrm{C}-\mathrm{PbI}_{2}$ based & 0.857 & 21.24 & 45.04 & 8.20 \\
& $(0.845 \pm 0.03)$ & $(21.02 \pm 0.33)$ & $(43.98 \pm 1.03)$ & $(7.82 \pm 0.34)$ \\
$155^{\circ} \mathrm{C}-\mathrm{PbI}_{2}$ based & 0.918 & 21.43 & 57.67 & 11.35 \\
& $(0.904 \pm 0.01)$ & $(21.47 \pm 0.10)$ & $(57.06 \pm 0.89)$ & $(11.08 \pm 0.32)$
\end{tabular}


Figures

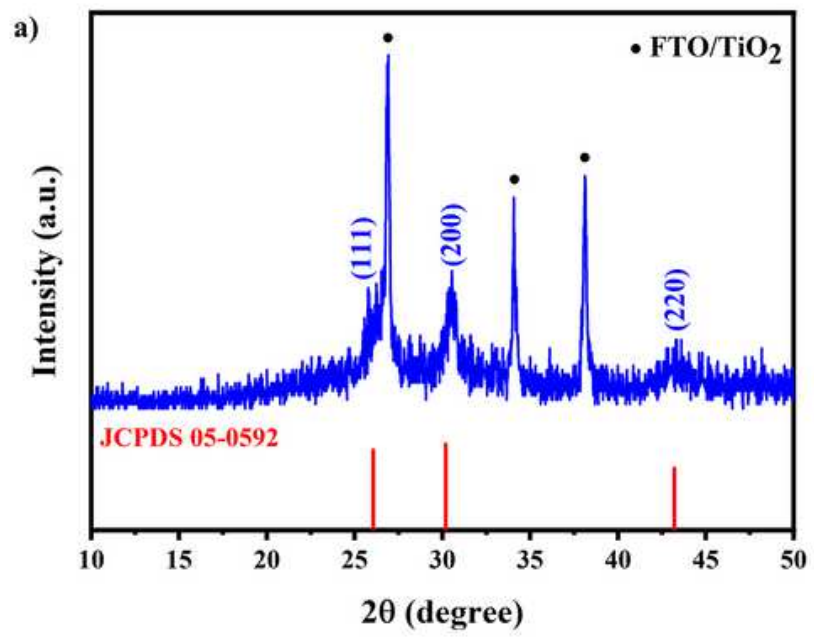

b)

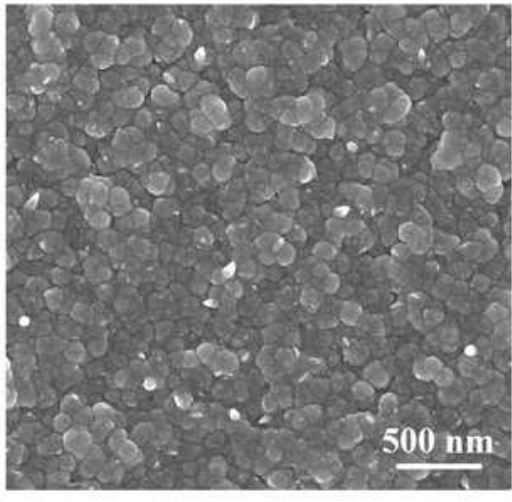

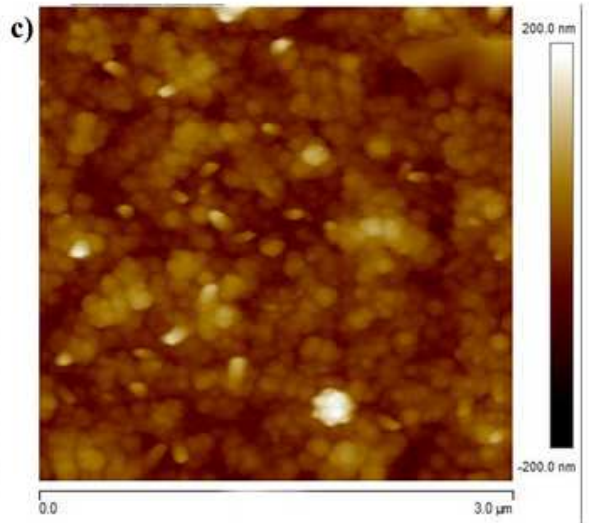

Average $=119 \mathrm{~nm}$

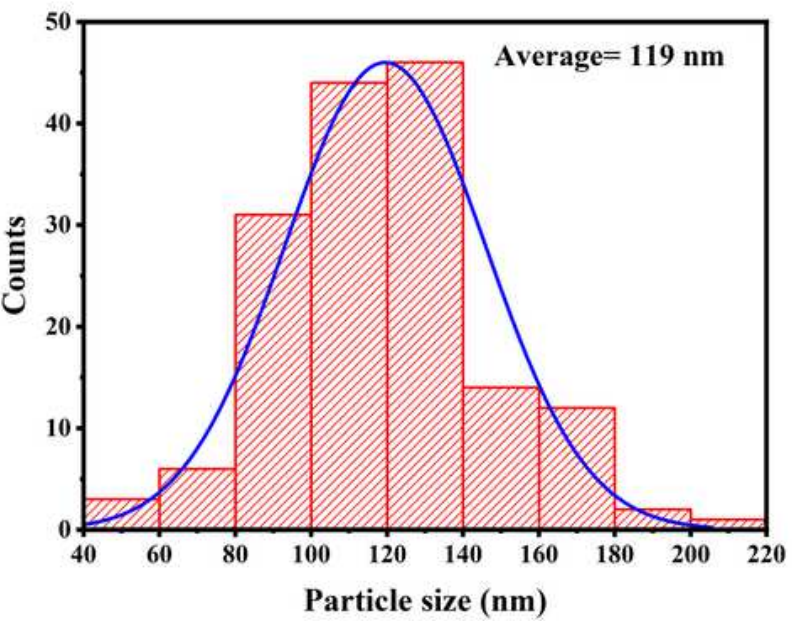

Figure 1

Structural and morphological characterization of chemically deposited PbS film. a) XRD diffraction pattern b) surface SEM image c) AFM image and d) grain size distribution histogram. 


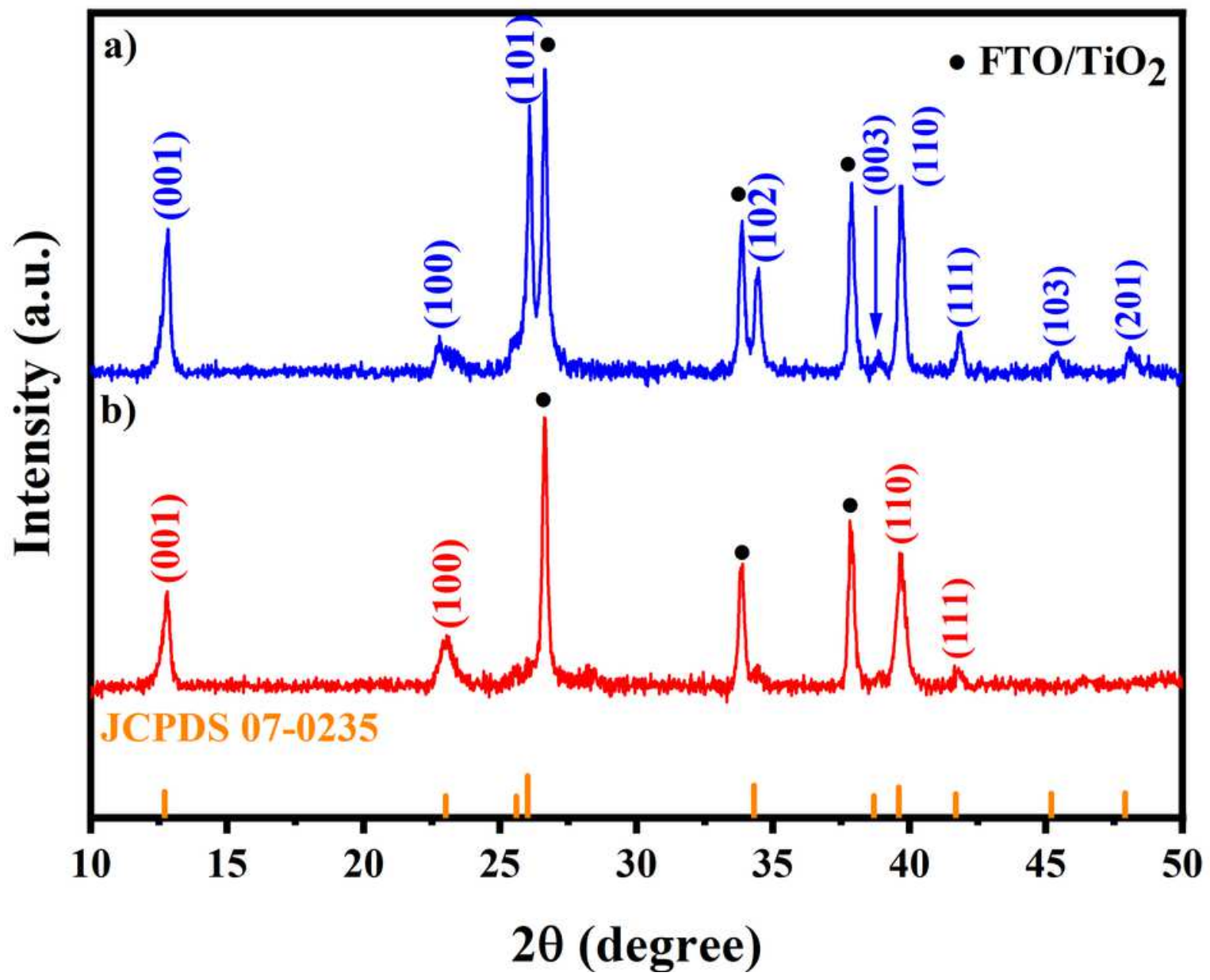

Figure 2

XRD patterns of $\mathrm{Pbl} 2$ films obtained from iodination of chemically deposited PbS films at a) 120 and b) $155^{\circ} \mathrm{C}$. 
a)

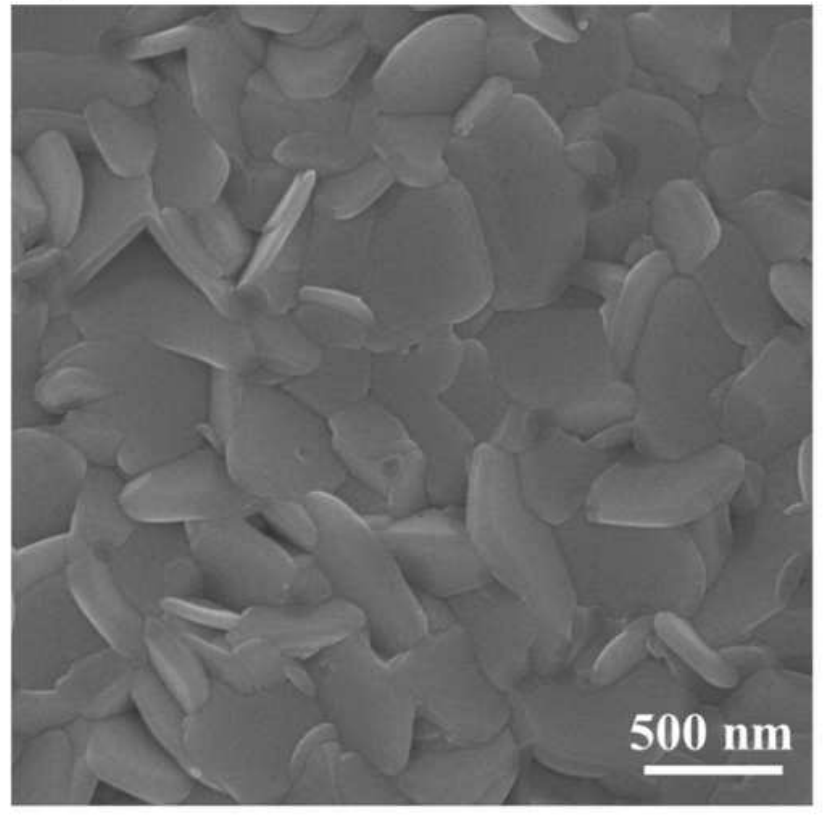

c)

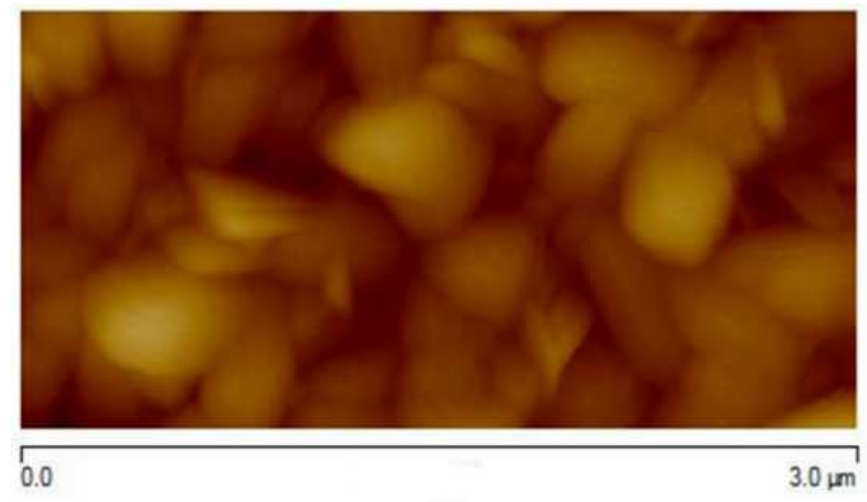

b)

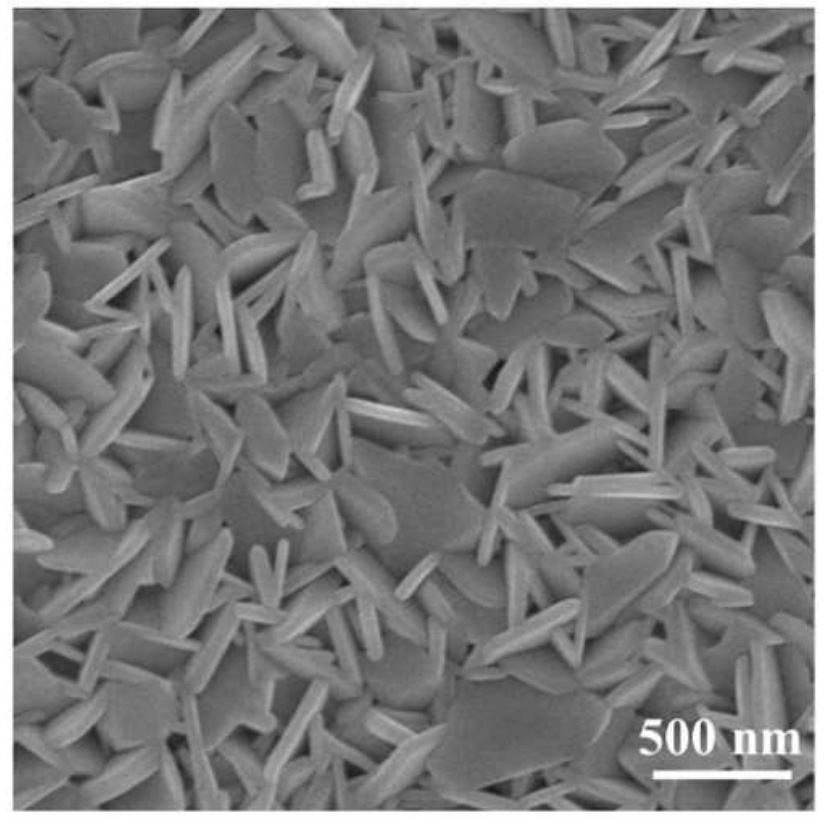

d)

$200.0 \mathrm{~nm}$

$200.0 \mathrm{~nm}$
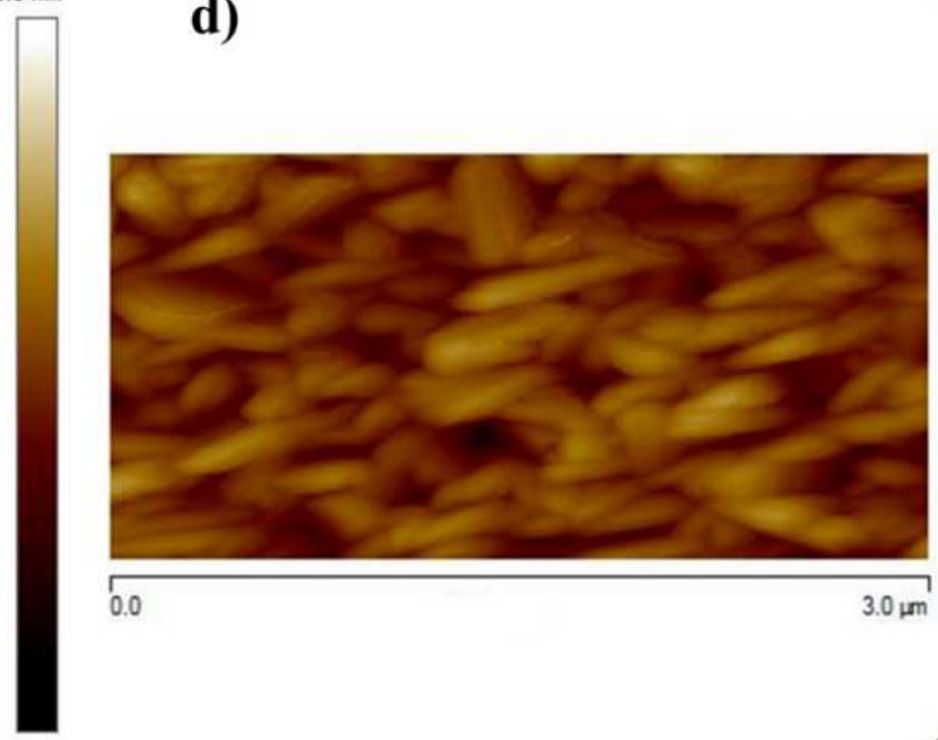

$3.0 \mathrm{~mm}$

$-200.0 \mathrm{~nm}$

\section{Figure 3}

Top surface SEM images and AFM images of PbI2 films obtained from iodination of chemically deposited PbS films at a,c) 120 and b,d) $155^{\circ} \mathrm{C}$. 


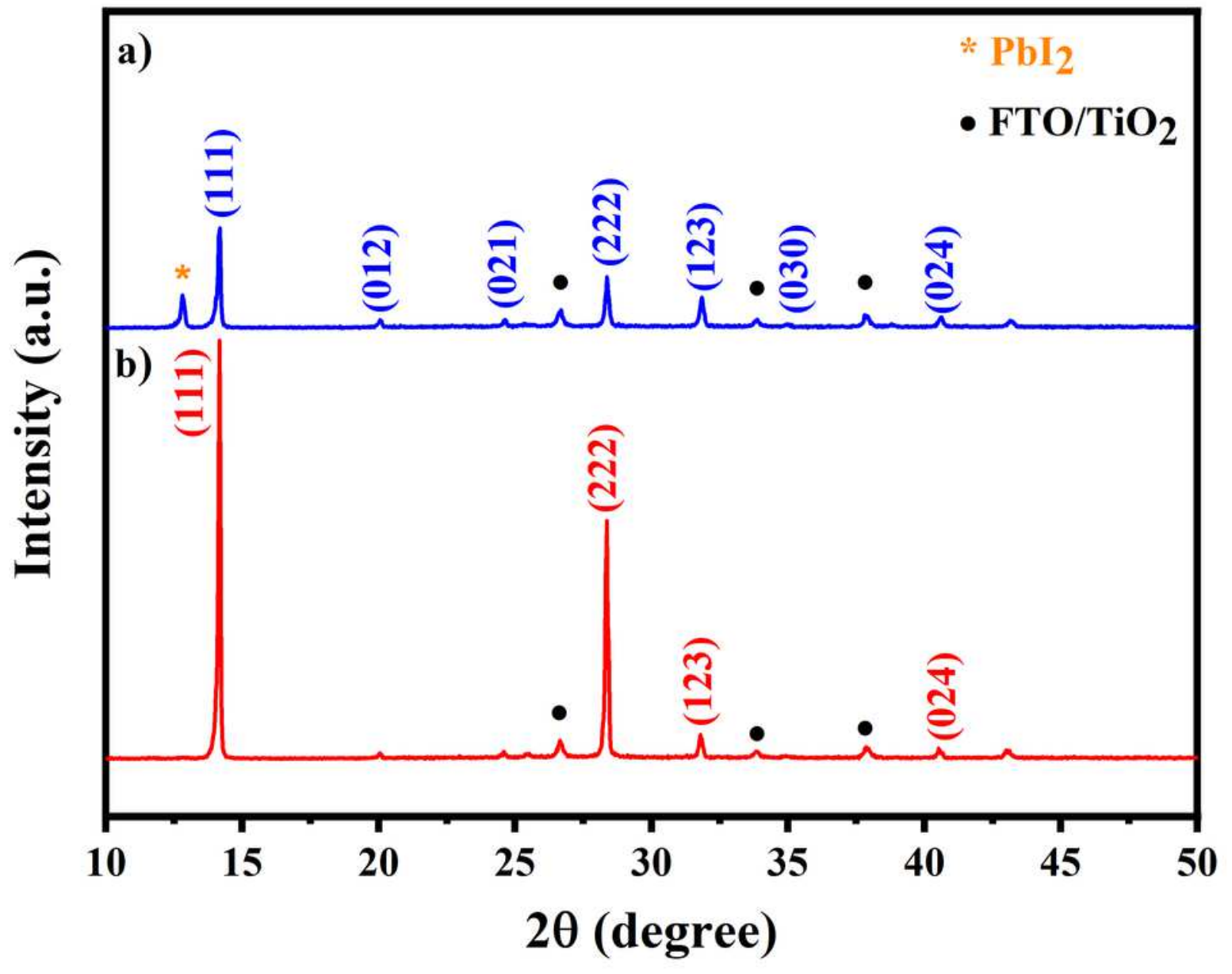

Figure 4

XRD patterns of perovskite films converted from a) $120^{\circ} \mathrm{C}-\mathrm{Pbl} 2$ and b) $155^{\circ} \mathrm{C}-\mathrm{Pbl} 2$. . 
a)

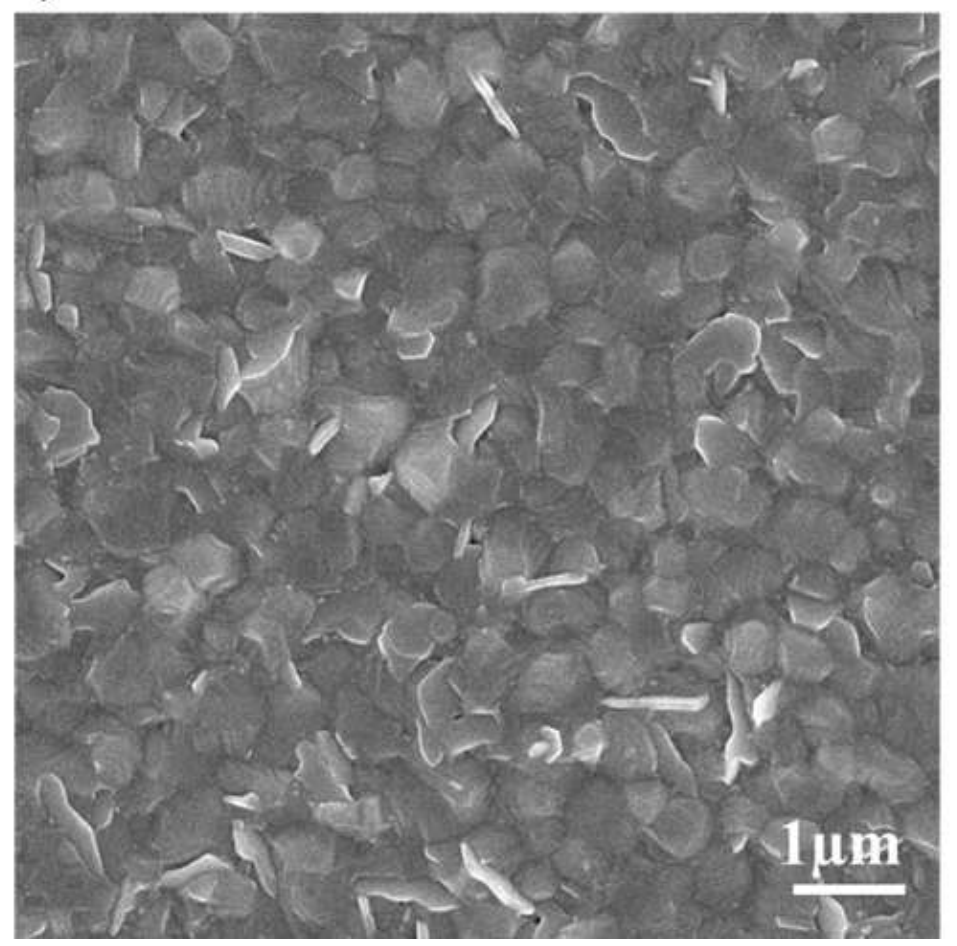

b)

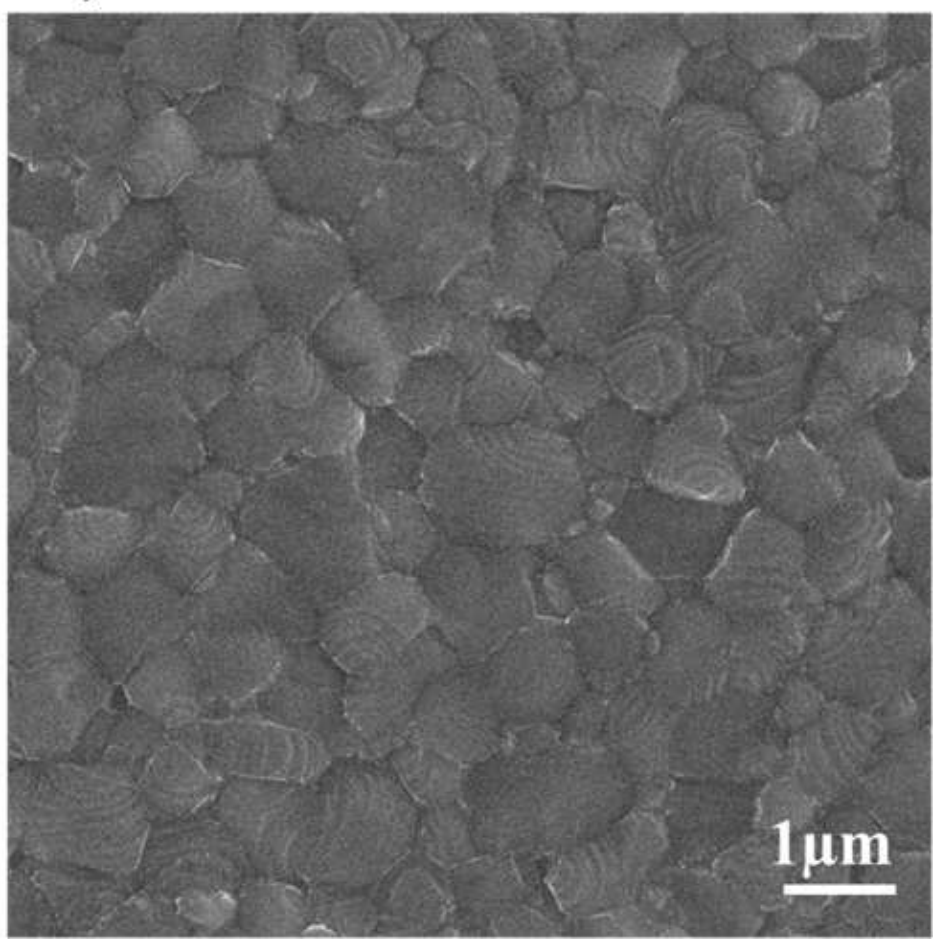

\section{Figure 5}

SEM images of perovskite films converted from a) $120^{\circ} \mathrm{C}$-Pbl2 and b) $155^{\circ} \mathrm{C}-\mathrm{Pbl} 2$.

a)

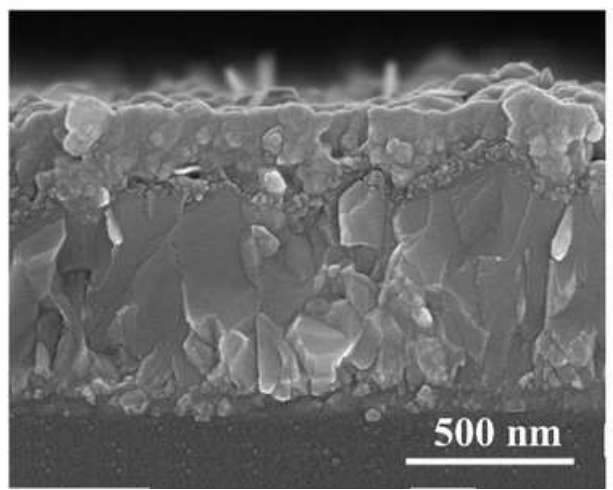

b)

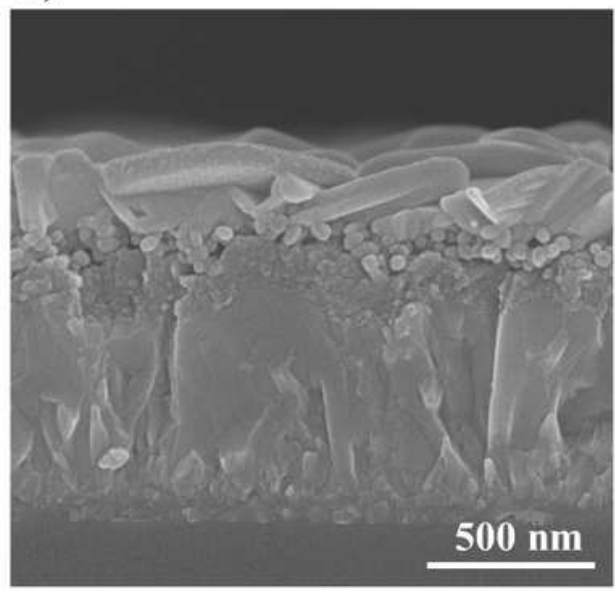

c)

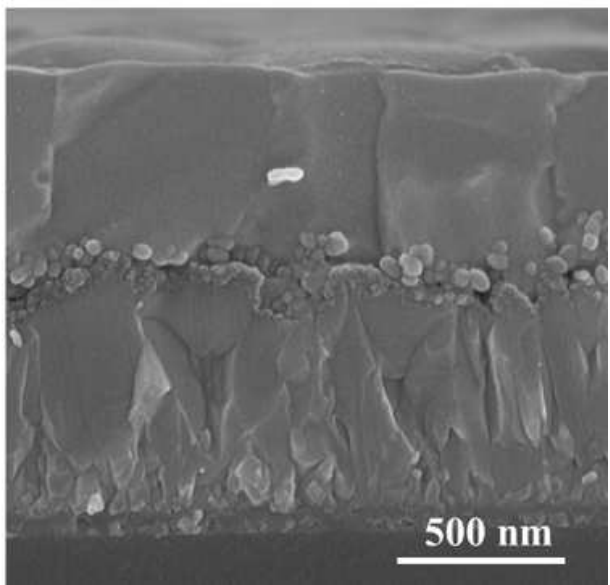

\section{Figure 6}

Cross sectional SEM image of a) PbS, b) Pbl2 and c) FAPbl3-based films on mp-TiO2/bl-TiO2/FTO substrate obtained after each step of multi-step chemical bath deposition assisted synthesis of halide perovskite film. 


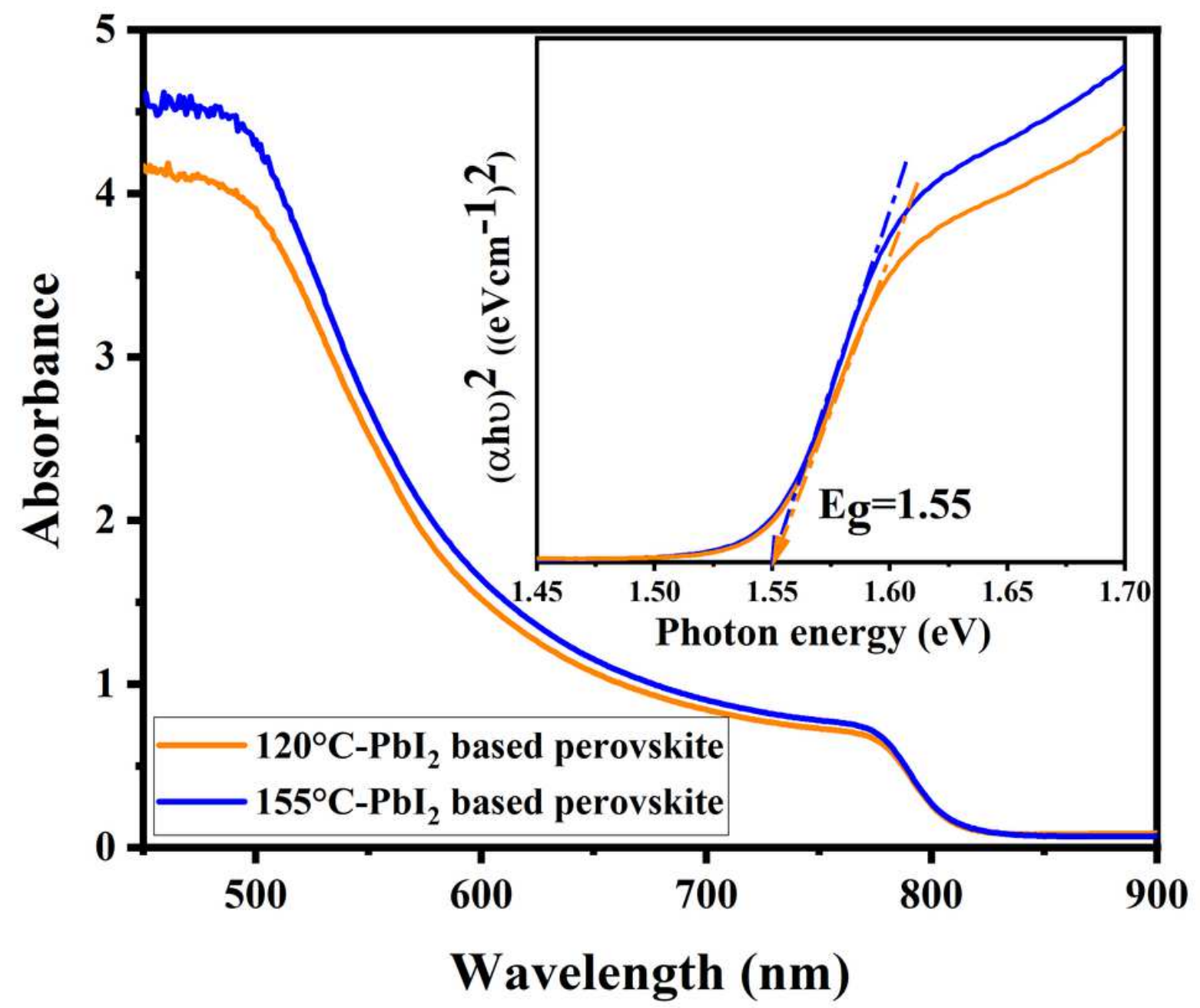

Figure 7

Absorption spectrum for the FAPbl3-based films produced from $120^{\circ} \mathrm{C}-\mathrm{Pbl} 2$ and $155^{\circ} \mathrm{C}-\mathrm{Pbl} 2$. 
a)

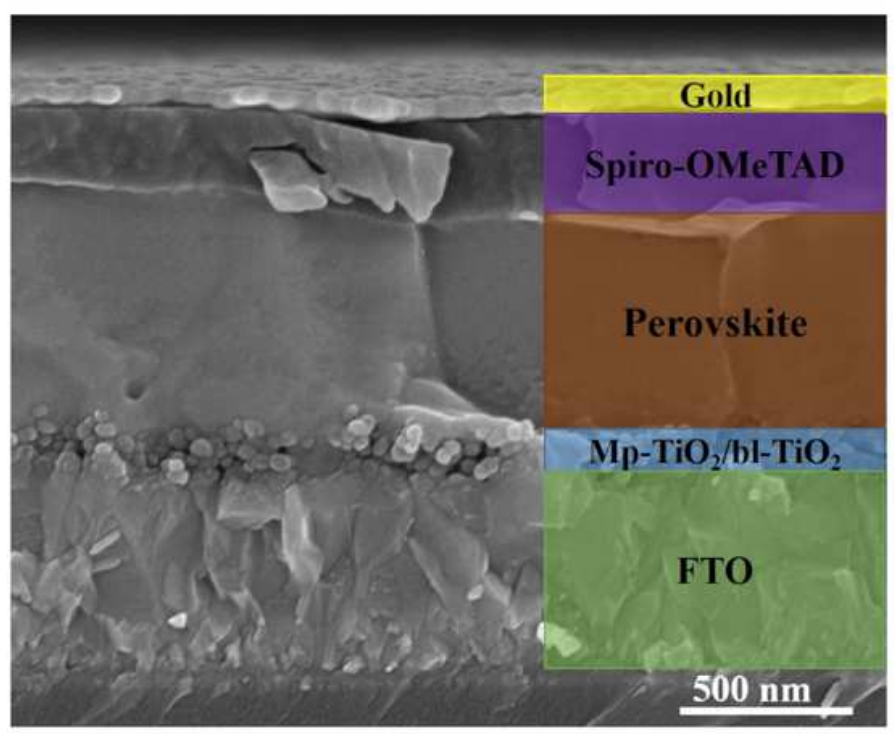

b)

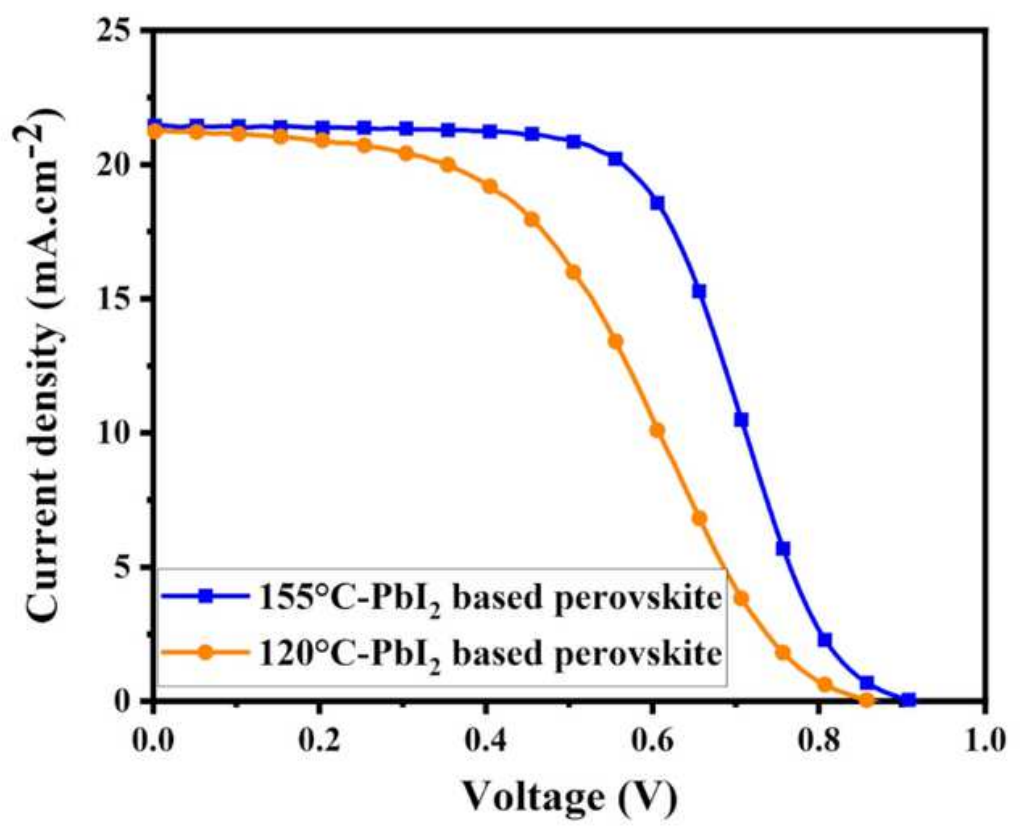

Figure 8

(a) Cross section SEM image of a FTO/bl-TiO2/mp-TiO2/perovskite/Spiro-OMeTAD/Au solar cell. b) Current-voltage characteristic of the best-performance devices based on $120^{\circ} \mathrm{C}-\mathrm{Pbl} 2$ and $155^{\circ} \mathrm{C}-\mathrm{Pbl} 2$.

\section{Supplementary Files}

This is a list of supplementary files associated with this preprint. Click to download.

- supplementaryNasirpouriAmended31May.docx 